\title{
Where No Law Has Gone Before: Space Resources, Subsequent Practice, and Humanity's Future in Space
}

\author{
CHRISTOPHER J. GAWRONSKI*
}

I. INTRODUCTION 175

II. LAW OF TREATIES AND SUBSEQUENT PRACTICE...........................181

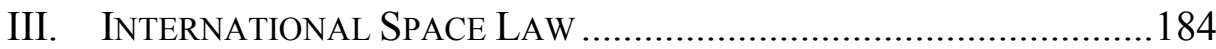

A. Space Law and the Outer Space Treaty ...............................185

B. Outer Space Treaty and Space Resources ............................186

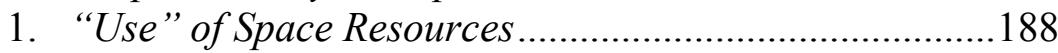

2. "Benefit" of Using Space Resources ..............................190

3. Sovereignty over Space Resources .................................193

C. Space Resources and the Results of Subsequent Practice ....194

IV. The SPACE ReSOURCE ACT .........................................................195

A. Compliance with the Outer Space Treaty ............................195

B. Promoting Subsequent Practice .............................................199

V. Using the Space Resource Act To Define Outer Space

TREATY OBLIGATIONS ..............................................................202

A. Enterprise-Driven Declaration of Benefits ..........................203

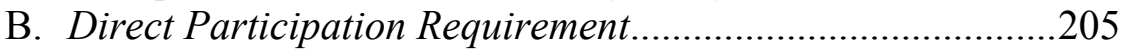

C. Space Resource Trust...........................................................206

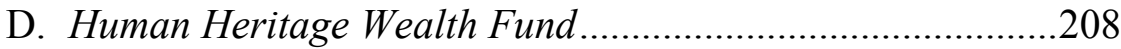

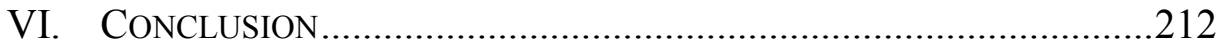

\section{INTRODUCTION}

Outer space, the "final frontier" in the iconic Star Trek series, ${ }^{1}$ is the subject of countless science fiction books and movies that display humanity's deep fascination with the possibilities of our species living among the stars. Many of these stories portray human societies more or less as we know them today but

*Editor in Chief, Ohio State Law Journal; J.D. Candidate, 2018, The Ohio State University Moritz College of Law; M.A. (Planning), University of British Columbia. After a lifetime of interest in astronomy and all things space, this Note represents my first professional foray into the cosmos; something I have approached both with excitement and no small amount of trepidation. To all of the people who have helped make this Note a reality, I am eternally grateful. I would like to extend a special thanks to Prof. Mohamed Helal for his patient guidance and thoughtful review of my early drafts. In addition, I would like to recognize the staff members of the Ohio State Law Journal, especially Courtney Kasuboski, for their role in preparing this Note for publication.

${ }^{1}$ TeeVees Greatest, Star Trek: The Original Series 1966-1969 Opening and Closing Theme, YouTUBE, at 00:00:06 (Apr. 27, 2016), https://www.youtube.com/watch?v=LIQsrv W6Ji4 (on file with Ohio State Law Journal) (excerpt from Star Trek, produced by Paramount Pictures). 
transplanted to a different setting, ${ }^{2}$ while others imagine a dramatically different way of living once separated from the constraints of Mother Earth. ${ }^{3}$ Either way, an inevitable and necessary part of any human society in space is the existence of laws that govern our activities and interactions with each other and our surroundings, including the use and ownership of the natural resources found in outer space. These "space resources" are now at the center of modern space law debates. This Note examines how the subsequent practice of states, and especially the recent U.S. Space Resource Act, informs the interpretation of the treaty regime that governs outer space and space resources.

The Outer Space Treaty, ${ }^{4}$ completed in 1967, originated in a set of principles 5 that discarded a history of colonial competition and territorial expansion by nations. ${ }^{6}$ Instead, a new legal order was established for outer space that was based on peace and cooperation among nations. ${ }^{7}$ This Treaty, with its visionary language and hopeful outlook, forms the foundation of international space law.

${ }^{2}$ See, e.g., ORSON SCOTT CARD, SPEAKER FOR THE DEAD (1986) (using as a setting two colonies on other worlds, one settled by Portuguese colonists and the other by Nordic colonists, that reflect the traditional cultures of the colonists).

${ }^{3}$ See, e.g., KIM StANLEY RoBInSON, GREEN MARS (1994) (describing the emergence of a uniquely Martian society in reaction to Earth-based precedents).

4 Treaty on Principles Governing the Activities of States in the Exploration and Use of Outer Space, Including the Moon and Other Celestial Bodies, opened for signature Jan. 27, 1967, 18 U.S.T. 2410, 610 U.N.T.S. 205 [hereinafter Outer Space Treaty].

${ }^{5}$ The formulation of an international legal regime for space activities began with the adoption of two U.N. General Assembly resolutions: the Resolution on International Co-operation in the Peaceful Uses of Outer Space, G.A. Res. 1721 (XVI) (Dec. 20, 1961), and the Declaration of Legal Principles Governing the Activities of States in the Exploration and Use of Outer Space, G.A. Res. 1962 (XVIII) (Dec. 13, 1963). The primary elements of both were ultimately incorporated into the Outer Space Treaty.

${ }^{6}$ See P.J. Blount \& Christian J. Robison, One Small Step: The Impact of the U.S. Commercial Space Launch Competitiveness Act of 2015 on the Exploitation of Resources in Outer Space, 18 N.C. J.L. \& TECH. 160, 164-65 (2016) (noting that the Outer Space Treaty separates "legal occupation from sovereignty" and represents an "anti-imperial or anticolonial" approach to outer space). Article II of the Treaty declares that "[o]uter space, including the moon and other celestial bodies, is not subject to national appropriation by claim of sovereignty, by means of use or occupation, or by any other means." Outer Space Treaty, supra note 4, art. II. This language makes outer space res communis (territory that is incapable of being made a part of any state) rather than terra nullius (territory that is currently unclaimed but capable of being acquired by a state through occupation and exercise of effective control). MALCOLM N. SHAW, INTERNATIONAL LAW 363, 393 (7th ed. 2014).

${ }^{7}$ Article III of the Treaty requires "States Parties ... shall carry on activities in the exploration and use of outer space . . in accordance with international law . . . in the interest of maintaining international peace and security and promoting international co-operation and understanding," while Article IV goes on to prohibit the placement of nuclear weapons in outer space, and to state that "[ $\mathrm{t}] \mathrm{he}$ moon and other celestial bodies shall be used by all States Parties ... exclusively for peaceful purposes. The establishment of military bases, . . the testing of any type of weapons and the conduct of military manœuvres on celestial bodies shall be forbidden." Outer Space Treaty, supra note 4, art. III, IV. 
As with any foundation, however, the Outer Space Treaty is only a starting point. It provides a basis upon which a comprehensive legal regime may be developed. After the Outer Space Treaty, four additional treaties were negotiated to fill in the details of various issues raised in the Outer Space Treaty. ${ }^{8}$ Three of these subsequent treaties addressed urgent issues faced by the parties as space activities accelerated through the 1960s and into the 1970s. ${ }^{9}$ However, one issue of prospective interest - the issue of how space resources may be used - was not resolved. Although an attempt was made to resolve it through the development of the Moon Agreement, ${ }^{10}$ the Agreement's tepid reception and the failure of most spacefaring nations to become parties ${ }^{11}$ leaves the existence and nature of rights to use and own space resources subject to broad interpretation. ${ }^{12}$

${ }^{8}$ The four treaties are the Agreement on the Rescue of Astronauts, the Return of Astronauts and the Return of Objects Launched into Outer Space (Rescue and Return Agreement), opened for signature Apr. 22, 1968, 19 U.S.T. 7570, 672 U.N.T.S. 119, the Convention on the International Liability for Damage Caused by Space Objects (Liability Convention), opened for signature Mar. 29, 1972, 24 U.S.T. 2389, 961 U.N.T.S. 187, the Convention on Registration of Objects Launched into Outer Space (Registration Convention), opened for signature Jan. 14, 1975, 28 U.S.T. 695, 1023 U.N.T.S. 15 [hereinafter Registration Convention], and the Agreement Governing the Activities of States on the Moon and Other Celestial Bodies, opened for signature Dec. 18, 1979, 1363 U.N.T.S. 3 [hereinafter Moon Agreement].

${ }^{9}$ See infra note 70.

${ }^{10}$ Moon Agreement, supra note 8, art. 11, para. 5 (declaring the intent of the parties to "undertake to establish an international régime, including appropriate procedures, to govern the exploitation of the natural resources of the moon").

${ }^{11}$ Currently there are only eighteen states parties to the Treaty, with Mexico and the Netherlands being the only parties with active space programs, and four signatory countries that have not ratified the Treaty, including only France and India with active space programs. U.N. Treaty Collection, Chapter XXIV Outer Space: Agreement Governing the Activities of States on the Moon and Other Celestial Bodies (Feb. 18, 2017), https://treaties.un.org/doc/Pub lication/MTDSG/Volume\%20II/Chapter\%20XXIV/XXIV-2.en.pdf [https://perma.cc/9NR6XSTN]; see Introduction to Space Activities, SPACE FOUND., https://www.spacefoundation. org/sites/default/files/downloads/IntroSpace_2017.pdf [https://perma.cc/36T5-ZWT8] (last updated Mar. 23, 2018) (surveying the space programs of nineteen countries and Europe). This is only $9 \%$ of the 193 U.N. member states. Overview, About the U.N., UNITED NATIONS, http://www.un.org/en/sections/about-un/overview/index.html [https://perma.cc/C769-LS2U].

12 Joanne Irene Gabrynowicz \& Jacqueline Etil Serrao, An Introduction to Space Law for Decision Makers, 30 J. SPACE L. 227, 232 (2004) ("The most controversial example of unresolved issues [in international space law] is the issue of the use of resources in space."); Michael Simpson, Future of Space Commercialisation-Mining Asteroid and Celestial Bodies, in COMMERCIALISATION OF SPACE 176, 178 (Bhupendra Jasani \& Ram Jakhu eds., 2014) (noting that legal scholars "differ widely in their opinions" regarding the question of "the right, if any, to own, possess, distribute and profit from mineral resources extracted from celestial bodies"). "[I]n the absence of any international case law on the matter," Simpson concludes that "the absolute declarations of publicists about the legal status of extracted material cannot constitute a definitive answer to the critical question: 'who owns it'?" Id.; see also discussion infra Part III. 
This lack of definition regarding rights to space resources does not seem to have created problems so far, which is probably due to the lack of sustained interest in activities beyond Earth orbit. But now, after more than four decades out of the limelight, the Moon is again an object of intense interest with proposals for missions to prospect and begin mining its resources. ${ }^{13}$ This time, reminiscent of the Gold Rush Era, ${ }^{14}$ the private sector is leading the charge. Eager private enterprises have identified resources on the Moon with high commercial value, such as helium-3. ${ }^{15}$ Some companies are looking even farther afield, targeting asteroids ${ }^{16}$ and Mars. ${ }^{17}$

As the overall activity of private enterprises pursuing missions beyond Earth orbit has increased, ${ }^{18}$ so has the urgency of questions about whether investments in the enterprises proposing to mine for resources are supported by a firm legal base, in particular a legal environment that recognizes ownership rights in the resources obtained by such missions. ${ }^{19}$ In response to this situation, the U.S. Congress passed, and the President signed, legislation containing the Space Resource Exploration and Utilization Act of 2015 (Space Resource Act). ${ }^{20}$ However, rather than clarifying the legal situation, this new law purporting to recognize property rights in space resources obtained by a private party has

${ }^{13}$ Ram Jakhu, Adequacy of the Law Governing Space Commercialisation, in COMMERCIALISATION OF SPACE, supra note 12, at 131, 140.

${ }^{14}$ Simpson, supra note 12 , at 182.

${ }^{15}$ Sarah Coffey, Note, Establishing a Legal Framework for Property Rights to Natural Resources in Outer Space, 41 CASE W. RES. J. INT'L L. 119, 121-24 (2009) (discussing the value of helium-3 and the likelihood of it driving future missions to the Moon).

${ }^{16}$ Asteroid Mining: An Unlimited Future for All Mankind, DEEP SPACE INDUSTRIES, https://deepspaceindustries.com/mining/ [https://perma.cc/JL88-6A5J]; Redefining Natural Resources, PlANETARY RESOURCES, https://www.planetaryresources.com/why-asteroids/ [https://perma.cc/N4YJ-FKRW].

${ }^{17}$ Nick Stockton, Elon Musk Announces His Plan To Colonize Mars and Save Humanity, WIRED (Sept. 27, 2016), https://www.wired.com/2016/09/elon-musk-colonize-mars/ [https://perma.cc/N7N7-BTD2].

${ }^{18}$ See Federal Aviation Administration Oversight of Commercial Space Transportation: Hearing Before the Subcomm. on Aviation of the H. Comm. on Transp. \& Infrastructure, 114th Cong. 35-36 (2016) (statement of Dr. George C. Nield, Assoc. Adm'r for Commercial Space Transp., Fed. Aviation Admin.) ("[T]he year 2015 was a recordsetting one for space ventures. The investment and debt financing in these enterprises totaled $\$ 2.7$ billion, with more venture capital invested in space in 2015 than in the prior 15 years combined.").

${ }^{19}$ Simpson, supra note 12, at 177-78; US Commercial Space Launch Competitiveness Act Signed into Law, BUS. L. BASICS, http://www.businesslawbasics.com/us-commercialspace-launch-competitiveness-act-signed-law [https://perma.cc/VVV3-6DFD] [hereinafter BUS. L. BASICS] (quoting a commentator who indicated that investors are concerned "about whether they'll plow millions (or billions) into a space mining company only to be told later that they broke the law").

20 The Space Resource Act was enacted as Title IV of the larger U.S. Commercial Space Launch Competitiveness Act. Space Resource Commercial Exploration and Utilization Act of 2015, Pub. L. No. 114-90, $\S \S 401-403,129$ Stat. 704, 720-22 (2015) (to be codified at 51 U.S.C. $\S 51301-51303)$. 
occasioned a spirited debate over whether it comports with the United States' obligations under the Outer Space Treaty. ${ }^{21}$

Much scholarship has been devoted to interpreting the obligations of the Outer Space Treaty pertaining to space resources. Most of this scholarship has concentrated on an analysis of the text itself and the preparatory work that went into the development of the Treaty. ${ }^{22}$ However, scholars have been divided in their analysis of the meaning of the Treaty's obligations. Now that the mining of the Moon and asteroids by private parties is an immediate concern, international space law's lack of definition on the subject of space resources presents a real difficulty, not just an interesting academic debate.

Why does it matter? It matters because the very foundation of international space law is the promotion of peace and cooperation in outer space. ${ }^{23}$ The ability of humanity to avoid conflict resulting from disputes over space resources depends on how this issue is addressed. ${ }^{24}$ If the governing rule for acquiring space resources becomes "first come first served," it is easy to contemplate how many countries may react negatively to being left out of a new resource boom. But also, the broader possibility of a reimagined human future in space is at stake. If we truly dare to envision a peaceful and cooperative future for humanity in space - the realization of the lofty aspirations articulated in the Outer Space Treaty - it is critical to clarify the meaning of the Treaty's obligations and rights relative to space resources in order to avoid the prospect of conflict, or even war.

In contrast to other scholarship surrounding the issue of space resources, this Note will analyze the broad, undefined terms ${ }^{25}$ in the Outer Space Treaty through the lens of the subsequent practice of the states that are parties to the Treaty. The analysis reveals that subsequent practice provides some definition to clarify property rights in space resources, but not enough to definitively answer the question of whether private parties are allowed to own space resources for commercial purposes. The Space Resource Act is a potential instrument of subsequent practice that the United States can use to shape the meaning of the unclear obligations. However, for this to work, this Note argues that the United States must implement the Space Resource Act in a way that other parties to the Outer Space Treaty agree is a good-faith interpretation of the Treaty. In this way, the United States will be part of a conversation defining the

${ }^{21}$ See infra Part IV.

22 See infra Part III.B.

${ }^{23}$ See supra note 7 (discussing Articles III and IV of the Outer Space Treaty).

${ }^{24}$ See Eilene Galloway, Maintaining International Space Cooperation for Peaceful Uses, 30 J. SPACE L. 311, 314-15 (2004) ("Commercial space uses ...could be accommodated as long as they are in compliance with the safety and order required for maintaining peace.").

25 There are no definitions provided in the Treaty, which is especially problematic for critical terms such as "use," "benefit," and "province of all mankind." Outer Space Treaty, supra note 4. 
proper meaning of the obligations under the Treaty instead of potentially being viewed as defying the Treaty. ${ }^{26}$

Because a private company in the United States is now close to sending the first private probe to the Moon, ${ }^{27}$ the United States needs to implement the policy contained in its new law in a way that reduces the likelihood of conflict and the potential undoing of a half-century legacy of peace in outer space. Perhaps more importantly, the interpretation pursued by the United States should truly embrace the aspirations of the Treaty. In doing so, the United States could once again, harkening back to President Kennedy's push to reach the Moon, ${ }^{28}$ demonstrate visionary leadership in the pursuit of a human future in space.

The analysis begins with an examination, in Part II, of the Vienna Convention on the Law of Treaties. This will consider the various methods used to interpret treaties and focus on the appropriate considerations for using the subsequent practice of states parties to help interpret treaties. Part III then reviews the components of international space law. In particular, the Outer Space Treaty is examined with a focus on the debate surrounding the application of its provisions to the question of space resources. These provisions will then be examined through the lens of subsequent practice. In Part IV, the Space Resource Act is examined as to whether or not it satisfies the United States' obligations under the Outer Space Treaty. An argument is then made regarding proactive use of the Act to shape the conduct of other states parties. Finally, in Part V, several approaches are proposed that could be used to support the United States' recognition of private ownership of space resources while more clearly satisfying the obligations imposed by the Outer Space Treaty. The suggested approaches are broadly intended to advance the debate on the meaning of Outer Space Treaty obligations as they pertain to space resources.

${ }^{26}$ See Thomas Gangale, The Development of Outer Space: Sovereignty AND PROPERTY RightS IN INTERNATIONAL SPACE LAW 38-39 (2009).

${ }^{27}$ Moon Express expects to launch its MX-1E mission in 2017. U.S. Government Approves Plan for Moon Express To Become First Private Company To Venture Beyond Earth's Orbit, MOON EXPRESS (Aug. 3, 2016), http://moonexpress.com/news/us-governmentapproves-plan-moon-express-become-first-private-company-venture-beyond-earths-orbit/ [https:// perma.cc/F4UX-2MPM] (noting that "Moon Express received the green light for pursuing its 2017 lunar mission"); see FED. AVIATION ADMIN., FACT SHEET-MOON EXPRESS PAYLOAD REVIEW DETERMINATION (Aug. 3, 2016), https://www.faa.gov/news/fact sheets/news story.cfm ?newsId=20595 [https://perma.cc/94XV-MDGE] ("On July 20, 2016, the FAA made a favorable payload determination for the Moon Express MX-1E mission.").

${ }^{28}$ President John F. Kennedy, Special Message by the President on Urgent National Needs to a Joint Session of the Congress 9 (May 25, 1961), https://www.jfklibrary.org/AssetViewer/Archives/JFKPOF-034-030.aspx [https://perma.cc/59G2-VX3X] ("I believe that this nation should commit itself to achieving the goal, before this decade is out, of landing a man on the moon and returning him safely to the earth. No single space project in this period will be more impressive to mankind, or more important for the long-range exploration of space ...."). 


\section{LAW OF TREATIES AND SUBSEQUENT PRACTICE}

The Vienna Convention on the Law of Treaties (VCLT) ${ }^{29}$ is an "essential" source of international law governing treaties. ${ }^{30}$ Rules for the interpretation of treaties are contained in Article 31.31 Although written into the VCLT, the treaty interpretation rules are recognized to be a statement of preexisting customary international law. ${ }^{32}$ This means that Article 31 is generally applicable to all treaties even if they were concluded before the VCLT came into force, and even if the states parties to such treaties are not parties to the VCLT. ${ }^{33}$ This is important because it means the treaty interpretation rules are applicable to both the Outer Space Treaty and the United States, even though the Outer Space Treaty came into force before the VCLT, ${ }^{34}$ and even though the United States has not ratified the VCLT. ${ }^{35}$

Article 31 articulates the general rule of treaty interpretation, which requires consideration of the following four basic elements:

1. "[T] he ordinary meaning" of the terms of the treaty "in their context and in the light of [the] object and purpose" of the treaty; 36

2. "Any subsequent agreement between the parties regarding the interpretation of the treaty or the application of its provisions;", 37

${ }^{29}$ Vienna Convention on the Law of Treaties, opened for signature May 23, 1969, 1155 U.N.T.S. 331 [hereinafter VCLT].

30 RiCHARD K. GARDINER, TREATY INTERPRETATION 6 (2d ed. 2015).

31 VCLT, supra note 29, art. 31.

32 GARDINER, supra note 30, at 13-20; SHAW, supra note 6, at 5 (explaining that customary international law comprises "state practices recognised by the community at large as laying down patterns of conduct that have to be complied with").

${ }^{33}$ GARDINER, supra note 30, at xv (noting that Article 31 "applie[s] to treaties old and new"); Luigi Crema, Subsequent Agreements and Subsequent Practice Within and Outside the Vienna Convention, in TREATIES AND SubSEQUeNT PRACTICE 13, 14-15 (Georg Nolte ed., 2013) (noting that Article 31 is "used in cases involving states not parties to the Vienna Convention").

34 The Outer Space Treaty came into force on October 10, 1967. Bureau of Arms Control, Verification, \& Compliance, Treaty on Principles Governing the Activities of States in the Exploration and Use of Outer Space, Including the Moon and Other Celestial Bodies, U.S. DEP'T ST., https://www.state.gov/t/isn/5181.htm [https://perma.cc/4TB7-NWQ5]. The VCLT came into force on January 27, 1980. U.N. Treaty Collection, Chapter XXIII Law of Treaties: Vienna Convention on the Law of Treaties, https://treaties.un.org/doc/Publication/ MTDSG/Volume\%20II/Chapter\%20XXIII/XXIII-1.en.pdf [https://perma.cc/A6H5-JTK4] (last updated Mar. 23, 2018).

35 The United States signed the VCLT on April 24, 1970, but has not subsequently ratified it. U.N. Treaty Collection, supra note 34. Nonetheless, the United States "considers many of the provisions of the [VCLT] to constitute customary international law." Vienna Convention on the Law of Treaties, U.S. DEP'T ST., https://www.state.gov/s/1/treaty/faqs/70139 .htm [https://perma.cc/2XWV-JPT7].

36 VCLT, supra note 29 , art. 31, para. 1.

${ }^{37} I d$. art. 31, para. 3(a). 
3. "Any subsequent practice in the application of the treaty which establishes the agreement of the parties regarding its interpretation;"38 and

4. "Any relevant rules of international law applicable in the relations between the parties." 39

It is important to note that there is no hierarchy or priority among these considerations. The elements are considered equally important and integral to the interpretation process; an interpreter can make "no firm conclusion based on particular elements [of a treaty] before the process [of interpretation] has been completed." 40 It may seem logical to start the interpretation process with the terms of a treaty and then proceed through the other elements in the order they are listed in the VCLT. However, interpretation should be viewed "as a recursive ... process that ... spiral[s] in toward the meaning of a treaty" rather than a strictly linear process. ${ }^{41}$ As a result, the subsequent practice of parties is an integral, indeed critical, element of any treaty interpretation process. ${ }^{42}$

But what exactly is subsequent practice? Practice is an official act, or commitment to act, in response to a treaty provision. ${ }^{43}$ Any kind of action could potentially qualify as practice ${ }^{44}$ so long as it is not a one-off action: some "element of constancy" is required. 45

To be subsequent practice, a practice must be understood to relate to the obligations of the specific treaty. Actions related to another treaty are not

${ }^{38} I d$. art. 31, para. 3(b).

${ }^{39} I d$. art. 31, para. 3(c).

${ }^{40}$ GARDINER, supra note 30 , at 32 .

41 Julian Davis Mortenson, The Travaux of Travaux: Is the Vienna Convention Hostile to Drafting History?, 107 AM. J. INT’L L. 780, 781 (2013).

${ }^{42}$ Christian DJefFal, Static AND Evolutive Treaty InTERPREtation 163 (2016) (noting with approval that use of subsequent practice "imports legal reality" into the interpretation of treaties).

${ }^{43}$ See GARDINER, supra note 30, at 254-55. By logical implication, this means that an action that does not comply with a treaty provision generally cannot be considered subsequent practice for treaty interpretation purposes. Id. at 280 (noting there is a "presumption that the parties [to a treaty] through their practice intend to interpret the treaty rather than change it"). However, where state practice relative to a treaty does not meet the ordinary meaning of the treaty text, and the state parties agree to the practice, it is possible for this to become subsequent practice that amounts to an amendment of the treaty. $I d$. at 275-80 (noting, among only a few examples, how the practice of using a veto in the U.N. Security Council does not comply with the terms of the U.N. Charter but has been accepted by all member countries through practice as a legitimate interpretation of the Charter).

${ }^{44} \mathrm{Id}$. at 254-55; see also ANTHONY A. D'AMATO, THE CONCEPT OF CUSTOM IN INTERNATIONAL LAW 134 (1971) (arguing that when a state's actions do not agree with statements by functionaries within its government, the actions should take precedence); $i d$. ("[I]t is an extremely dubious proposition to rely upon the arguments of governments, expressed either through their attorneys or foreign offices, rather than their acts.").

${ }^{45}$ GARDINER, supra note 30 , at 259 . 
necessarily relevant even if the treaty is on a related topic. ${ }^{46}$ Therefore, it must be clear that the practice is undertaken in application of the treaty provisions. In general, the weight to be given to any subsequent practice depends on the "clarity and specificity" of the practice and "whether and how it is repeated." 47

A critical consideration is whose subsequent practice matters. An action must be done directly by, or be attributable to, a state party to have value as subsequent practice. ${ }^{48}$ Also, there could be many parties acting, or just one. ${ }^{49}$ Recall that subsequent practice must "establish[] the agreement of the parties." 50 In the context of a multilateral treaty, the actions of all parties must exhibit some measure of concordance, ${ }^{51}$ or the action of a single party must be followed by the "manifested or imputable" agreement of the other parties that the action reflects an accurate interpretation of the treaty. ${ }^{52}$ Importantly, silence or inaction may be interpreted as agreement, especially if an action by one party "calls for a reaction by another" and there is none. ${ }^{53}$ Therefore, subsequent practice does not require there to be "abundant practice by all parties to [a] treaty" 54 so long as the practice of some parties is supported by "good evidence that the other parties have endorsed the practice." 55

It is critical to note that the VCLT specifies "[a] treaty shall be interpreted in good faith."56 Good faith, in this case, "indicates how the task of interpretation is to be undertaken." 57 The result of a good-faith interpretation would be an understanding of a treaty's terms that "reflect[s] effectively the true intentions" of the parties. ${ }^{58}$ In other words, the interpretation reflects "the spirit of the treaty and not [necessarily] its mere literal meaning." 59

While not specifically defined in the VCLT, good faith can be understood to have three aspects. First, good faith with regard to treaties requires reasonableness in both interpretation and the performance of obligations. ${ }^{60}$

${ }^{46} I d$. at 225-26. However, other treaties may contribute to relevant rules of international law applicable between the parties. Id. at 299-302.

${ }^{47}$ Int'l Law Comm'n, Rep. on the Work of Its Sixty-Eighth Session, at 122, U.N. Doc. $\mathrm{A} / 71 / 10$ (2016).

${ }^{48}$ GARDINER, supra note 30, at 266; see also DJEFFAL, supra note 42, at 165 (noting that "Art. 31(3) VCLT does not expressly limit subsequent practice to states").

${ }^{49}$ GARDINER, supra note 30 , at 270 .

${ }^{50}$ VCLT, supra note 29, art. 31, para. 3(b). For treaties to have binding force, "[t]he consent of the states parties . . . is a vital factor, since states may . . . be bound only by their consent." SHAW, supra note 6, at 660.

${ }^{51}$ GARDINER, supra note 30, at 269.

$52 \mathrm{Id}$. at 267.

53 Id. at 264; see also Int'l Law Comm'n, supra note 47, at 122.

${ }^{54}$ GARDINER, supra note 30 , at 270.

${ }^{55} \mathrm{Id}$.

56 VCLT, supra note 29, art. 31, para. 1.

57 GARDINER, supra note 30, at 171 .

$58 \mathrm{Id}$. at 172.

${ }^{59}$ Bin Cheng, General Principles of LAW As ApPlied by InTERnational Courts AND TRIBUNALS 114 (1953).

${ }^{60}$ GARDINER, supra note 30, at 176. 
Second, good faith "may demand a form of balancing of rights and obligations" such that a party does not act arbitrarily or abuse its rights. ${ }^{61}$ One party to a treaty should not abuse its position or rights - even sovereign rights ${ }^{62}$ — but rather "be fair and equitable as between the parties" and not undertake actions "calculated to procure ... an unfair advantage" or "to prejudice the interests of the other contracting part[ies]."63 Finally, good faith requires interpreting a treaty so as to give effect to all its provisions rather than negating the effect of some provisions as a result of the interpretation of others. ${ }^{64}$ Also, good faith does not apply only to interpretation. Part III of the VCLT begins with the general premise that all treaties "must be performed by [the parties] in good faith." 65 So, good faith is a critical element of both interpretation and performance of treaties, not surprising since interpretation of a treaty obligation is a necessary precursor to performing that obligation. ${ }^{66}$

In summary, subsequent practice is the consistent and concordant actions attributable to states parties to a treaty, or acquiescence to other party's actions, that apply a treaty provision based on a good-faith interpretation of the treaty, and that demonstrate the agreement of the parties as to the provision's meaning. When combined with the other elements of interpretation, subsequent practice helps provide a full picture of what the parties to a treaty meant by the treaty's provisions. With regard to the Outer Space Treaty, as discussed in Part III, subsequent practice actually reveals some agreement of the parties, though limited, regarding the interpretation of provisions relative to the ownership of space resources.

\section{INTERNATIONAL SPACE LAW}

The Outer Space Treaty comprises the core of international space law. However, the vagueness of key provisions of the Treaty has led to much debate over the nature and extent of rights and obligations regarding space resources. By looking beyond the Treaty text to the subsequent practice of states parties to the Treaty, in accordance with the VCLT, it is possible to more clearly define the international rights and obligations under the Outer Space Treaty. Unfortunately, subsequent practice to date has not been sufficient to conclusively answer the extent to which private use or ownership of space resources is recognized under international law.

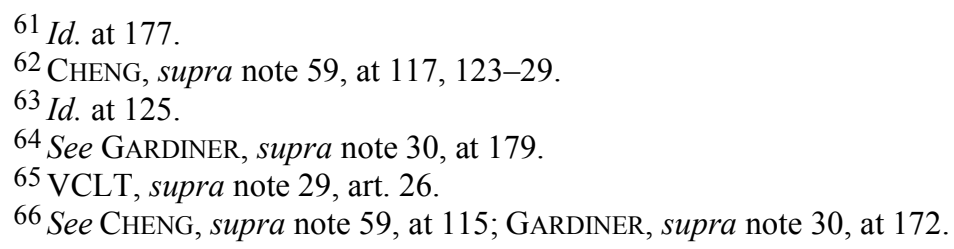




\section{A. Space Law and the Outer Space Treaty}

International space law comprises a core suite of four treaties ${ }^{67}$ that work in partnership with one another. ${ }^{68}$ The Outer Space Treaty was the first of these treaties to be concluded and provides the overall framework for all of space law. ${ }^{69}$ Subsequent space treaties refer to and further develop issues first identified in the Outer Space Treaty. ${ }^{70}$ Significantly, all spacefaring countries are parties to the Outer Space Treaty, which has the most states parties of any space treaty. ${ }^{71}$

The Outer Space Treaty is a lofty document laying out the international community's aspirations for outer space. In the preamble of the Treaty, the parties declare their belief that space exploration "should be carried on for the benefit of all peoples" and will "contribute to broad international co-

67 The other "core" space treaties are the Rescue and Return Agreement, the Liability Convention, and the Registration Convention. See Gabrynowicz \& Serrao, supra note 12, at 228; Comm. on the Peaceful Uses of Outer Space, Unedited Transcript of the Legal Subcommittee on Its 656th Meeting, at 11 (Apr. 2, 2002) [hereinafter COPUOS Transcript], http://www.unoosa.org/pdf/reports/transcripts/legal/LEGALT_656E.pdf [https://perma.cc/8XNWZ2GC] (remarks by U.S. Ambassador Kenneth Brill).

${ }^{68}$ Of course, the treaties also work in conjunction with any relevant customary international law and general principles of international law.

69 The Outer Space Treaty has been referred to as the "constitution" or "Magna Carta" of space law. Gabrynowicz \& Serrao, supra note 12, at 228; Eilene Galloway, The United States and the 1967 Treaty on Outer Space, 40 PROC. ON L. OUTER SPACE 18, 27 (1997); F.G. von der Dunk, The Origins of Authorisation: Article VI of the Outer Space Treaty and International Space Law, in NATIONAL SPACE LEGISLATION IN EUROPE 3, 8 (Frans G. von der Dunk ed., 2011).

70 The Rescue and Return Agreement is an elaboration of Article V of the Outer Space Treaty, the Liability Convention is an elaboration of Article VII of the Outer Space Treaty, and the Registration Convention is an elaboration of Article VIII of the Outer Space Treaty. Fabio Tronchetti, Fundamentals of Space LaW AND Policy 9-13, $28-29$ (Joseph N. Pelton ed., 2013); see also Galloway, supra note 69, at 27 (describing how "the first three international space agreements... represent extensions of articles in the" Outer Space Treaty).

${ }^{71}$ Currently, there are 107 states parties to the Outer Space Treaty, including all spacefaring countries. Outer Space Treaty, WIKIPEDIA, https:/en.wikipedia.org/wiki/Outer Space Treaty [https://perma.cc/35SS-7EGZ] (last updated Feb. 3, 2018) (listing the states parties and twenty-three nonparty signatories to the Outer Space Treaty); see also Comm. on the Peaceful Uses of Outer Space, Legal Subcomm., Status of International Agreements Relating to Activities in Outer Space as at 1 January 2017, U.N. Doc. A/AC.105/C.2/2017/CRP.7, at 12 (2017) (showing 105 states as parties); Press Release, Malta Ministry for Foreign Affairs and Trade Promotion, Malta Accedes to the "Outer Space Treaty" (May 26, 2017), https://foreignaffairs.gov.mt/en/Embassies/Hc_London/Pages/News/ Malta-accedes-to-the- $\%$ E2\%80\%9COuter-Space-Treaty\%E2\%80\%9D.aspx [https://perma.cc/ 823M-99AS]; Office for Outer Space Affairs, Status of International Agreements Relating to Activities in Outer Space, UNITED NATIONS, http://www.unoosa.org/oosa/en/ourwork/spacelaw/ treaties/status/index.html [https://perma.cc/2VZS-UP97] (showing Nicaragua's ratification of the Outer Space Treaty in 2017). 
operation."72 The preamble goes on to say that "such co-operation will contribute to the development of mutual understanding and... friendly relations between States and peoples."73

Although the Outer Space Treaty literally encompasses the universe, it does so without specific, detailed provisions or even definitions of its terms. This has given rise to the current debate over whether and how a private party can use or obtain ownership rights in space resources.

\section{B. Outer Space Treaty and Space Resources}

The basic beliefs stated in the preamble of the Outer Space Treaty form the backdrop for the substantive articles that articulate the broad rights of states in outer space and the parameters constraining the exercise of those rights. Debates around the right to use or own space resources focus on a few main provisions of the Outer Space Treaty that discuss the "use" of outer space and the "benefit" of that use. Article I of the Treaty provides that "[o]uter space . . . shall be free for exploration and use by all States without discrimination of any kind." 74 Some commentators argue that the freedom to "use" outer space, as articulated in this provision, must reasonably include the extraction of resources. This broad interpretation is based variously on specific wording ${ }^{75}$ the overall sense of the treaty, ${ }^{76}$ and the general premise that "international law permits freedom of action for states, unless there is a rule constraining" a particular action. ${ }^{77}$

Article VI of the Treaty discusses the role of private entities in outer space. Activity by nongovernmental entities is allowed, but the "activities of non-governmental entities in outer space... require authorization and continuing supervision" by a state. ${ }^{78}$ States "bear international responsibility" for any problems caused by nongovernmental entities because they are responsible for "assuring that national activities [in outer space] are carried out in conformity with the provisions [of the] Treaty." 79 However, states are free to establish their own regimes for authorization and supervision. ${ }^{80}$ This, according to commentators favoring a broad interpretation, taken together with the

72 Outer Space Treaty, supra note 4, at pmbl.

${ }^{73} \mathrm{Id}$.

${ }^{74} I d$. art. I, para. 2.

75 H.L. VAN TRAa-ENGelman, COMmercial Utilization OF OUTER SPACE 20 (1993) (observing that "[ $\mathrm{t}] \mathrm{h}$ combination of the two words 'exploration' and 'use' indicates the possibility of a type of use being more comprehensive" than if the word "exploration" alone had been used).

${ }^{76}$ Stephen E. Doyle, Using Extraterrestrial Resources Under the Moon Agreement of 1979, 26 J. SPACE L. 111, 116 (1998) ("In its total impression, the 1967 OST is an enabling treaty ... it is not restrictive.").

77 SHAW, supra note 6, at 154.

78 Outer Space Treaty, supra note 4, art. VI.

${ }^{79} \mathrm{Id}$

${ }^{80}$ See Galloway, supra note 24, at 315 (noting that the United States can "decide how to implement its international responsibility for national space activities"). 
freedom to "use" outer space established in Article I, demonstrates that the Outer Space Treaty specifically allows private (nongovernmental) entities to extract space resources (use outer space) for commercial purposes ${ }^{81}$ so long as they are regulated (authorized and supervised) by a state.

Other commentators argue that the "use" of outer space permitted in Article I is more limited. They base their narrower interpretation on the prohibition against "national appropriation" 82 of outer space, a critical limitation on the rights of states parties, found in Article II. The argument is that this prohibition in Article II completely bars a country from recognizing ownership of space resources. ${ }^{83}$ Others argue that even if ownership in space resources could be recognized without implicating claims of sovereignty, outer space must be used for the "benefit and in the interests of all countries" because it is the "province of all mankind." 84

Some commentators have argued that, although the Outer Space Treaty uses the concept "province of all mankind," outer space should actually be understood to be the "common heritage of mankind," 85 which means that "all humanity has the right to share in the benefits of [commercial use]." 86 Such an understanding would prevent any one entity from legally owning space resources without some agreed sharing of benefits. Most commentators, however, stress a distinction between the two concepts noting that province refers to a "nonexclusive right to use and explore space," whereas heritage refers to the "potential extraction of resources, and resource allocation." 87 This majority viewpoint avoids applying the "common heritage" standard to space resources under the Outer Space Treaty. Regardless of the standard, the argument is that no party, whether governmental or nongovernmental, can extract resources solely for its own benefit.

${ }^{81}$ VAN TRAA-ENGELMAN, supra note 75, at 22 (asserting that allowing "space activities by the private sector automatically introduce[s] the commercial aspect").

82 Outer Space Treaty, supra note 4, art. II.

83 The argument is that the very recognition of ownership is a national appropriation by exercise of sovereignty and, therefore, is prohibited by the Treaty. Fabio Tronchetti, Title IV-Space Resource Exploration and Utilization of the US Commercial Space Launch Competitiveness Act: A Legal and Political Assessment, 41 AIR \& SPACE L. 143, 145-46 (2016); cf. BIn Cheng, The 1967 Space Treaty, in STUDiES IN INTERNATIONAL SPACE LAW 215,234 (1997) (recounting suggestions that even if sovereignty is not implicated, "the semipermanent occupation of ...celestial bodies for purposes of exploitation will pose problems").

${ }^{84}$ Outer Space Treaty, supra note 4, art. I, para. 1.

85 Aldo Armando Cocca, Prospective Space Law, 26 J. SpACE L. 51, 53 (1998).

${ }^{86}$ BIN CHEng, The Legal Regime of Airspace and Outer Space: The Boundary Problem; Functionalism Versus Spatialism: The Major Premises, in STUDIES IN INTERNATIONAL SPACE LAW 425, 436 (1997) (describing the common-heritage-of-mankind concept as "convey[ing] the idea that the management, exploitation and distribution of the natural resources of [an] area ... are matters to be decided by the international community ... and are not to be left to the initiative and discretion of individual States or their nationals"); Cocca, supra note 85, at 53.

${ }^{87}$ E.g., Gabrynowicz \& Serrao, supra note 12, at 229. 
When drafting the Outer Space Treaty, delegates to the Legal Subcommittee of the U.N. Committee on the Peaceful Uses of Outer Space (COPUOS) were aware of the potential contradiction created by the terms of the treaty, which both guarantee use of outer space but prohibit its appropriation. ${ }^{88}$ Nevertheless, the final text of the Outer Space Treaty lacks definitions for its terms and retains the apparent contradiction (so textual arguments about the status of space resources are bound to be inconclusive). At one point, parties to the Outer Space Treaty negotiated a subsequent agreement to clarify the issue of space resources: the Moon Agreement. ${ }^{89}$ However, this agreement has attracted only minimal support ${ }^{90}$ and has failed to garner the signature or ratification of the major spacefaring countries, including the United States. ${ }^{91}$

Since the ordinary meaning of the Outer Space Treaty's terms creates ambiguity, and no subsequent agreement that clarifies the meaning of the terms as they pertain to space resources is in force between most of the parties, the interpretative requirements of Article 31 of the VCLT indicate that subsequent practice takes on great significance in interpreting the meaning of these treaty rights and obligations. ${ }^{92}$ While there had not been a broad array of subsequent practice in the use of space resources prior to the passage of the Space Resource Act, there had been enough to suggest some clarification for the meaning of the terms "use" and "benefit" in the Outer Space Treaty.

\section{1. "Use" of Space Resources}

Space resources have been in use for many years. Perhaps the most famous are the lunar samples (Moon rocks) obtained by the United States and Soviet Union during the heyday of lunar exploration after the Outer Space Treaty came into force in $1967 .{ }^{93}$ More recently, Japan collected materials from an asteroid

${ }^{88}$ French delegate Mr. Seydoux questioned "how far the principle of non-appropriation was compatible with effective exploration and exploitation." Comm. on the Peaceful Uses of Outer Space, Summary Rec. of the Legal Subcomm. on Its 57th Meeting, at 16, U.N. Doc. A/AC.105/C.2/SR.57 (Oct. 20, 1966).

${ }^{89}$ Moon Agreement, supra note 8, at pmbl.

90 This lack of support likely results from the significant controversy that surrounded the provisions related to space resources. Seven years, from 1972-1979, were spent negotiating language related to the "disposition of the potential benefits resulting from the exploitation and use of [space] resources." CARL Q. CHRISTOL, THE MODERN INTERNATIONAL LAW OF OUTER SPACE 348 (1982). As late as 1978, the issue of a benefitsharing regime "seemed almost insurmountable." Id. at 356.

91 See supra note 11.

92 See supra Part II.

93 The U.S. Apollo missions returned from the Moon with a total of 842 pounds of lunar material between 1969 and 1972. NAT'L AERONAUtics \& SPACE AdMin., OfFICE OF INSPECTOR GEN., NASA'S MANAGEMENT OF MOON ROCKS AND OTHER ASTROMATERIALS LOANED For RESEARCh, EduCATION, AND PUblic DisPlay, RePort No. IG-12-007, at 1 (2011). 
during its Hayabusa mission launched in 2003.94 In the United States, the Moon rocks have been used for scientific research, and for goodwill and education purposes. ${ }^{95}$ Importantly, the U.S. government has consistently asserted its ownership over the Moon rocks. ${ }^{96}$ In 1973, the U.S. government also made a gift of a Moon rock to every U.S. state and various countries as a gesture of friendship. ${ }^{97}$ In cases when these Moon rocks have been lost or stolen, the United States has successfully demanded their return claiming them to be government property. ${ }^{98}$ Other countries have not opposed these claims. ${ }^{99}$ In addition, other countries are continuing to visit the Moon to obtain their own lunar samples. ${ }^{100}$ This ongoing practice by some countries and apparent acceptance of the practice by others would suggest agreement among states that governments can own mineral resources extracted from a celestial body, especially if used for scientific, goodwill, or educational purposes. ${ }^{101}$

${ }^{94} \mathrm{Id}$. at 2.

$95 \mathrm{Id}$. at $4-7$.

${ }^{96} \mathrm{See}$ id. at 2 ("NASA's collection of astromaterials is the property of the U.S. Government ....").

${ }^{97}$ These rocks were fragments of a rock collected on the last Apollo mission named the Goodwill Moon Rock. Id. at 7.

98 Matthew J. Kleiman, The LitTle BoOK of Space Law 158-60 (2013). In one case, a federal judge recognized a stolen fragment of the Goodwill Moon Rock as being "national property" of Honduras after the United States, being the original owner of the rock, made a gift of it in 1973. United States v. One Lucite Ball Containing Lunar Material, 252 F. Supp. 2d 1367, 1373, 1376 (S.D. Fla. 2003).

${ }^{99}$ See Tronchetti, supra note 83, at 146. Recall that failure to act can be considered subsequent practice where an action would be expected. See supra note 53.

${ }^{100}$ China's lunar program began in 2007, and its first mission to return lunar samples, called "Chang'e-5," is currently scheduled for launch in 2019 after being postponed due to a launch failure in 2017. China Expects To Launch Fifth Lunar Probe Chang'e-5 in 2017, CHINA NAT'L SPACE ADMIN. (Mar. 2, 2011), http://www.cnsa.gov.cn/n6443408/n6465719/c64 78841/content.html [https://perma.cc/KZ7B-DNRV]; Jeff Foust, Long March 5 Failure To Postpone China's Lunar Exploration Program, SpaceNews (Sept. 25, 2017), http://spacenews.com/long-march-5-failure-to-postpone-chinas-lunar-exploration-program/ [https://perma.cc/69Z5-R6SU]; David R. Williams, Future Chinese Lunar Missions, NASA, https://nssdc.gsfc.nasa.gov/planetary/lunar/cnsa moon_future.html [https://perma.cc/K33Z-9H4A] (last updated Oct. 3, 2017). Ultimately, China's lunar exploration plans include mining of lunar resources. Vikram Mansharamani, China Wants To Mine the Moon for 'Space Gold,' PBS (Mar. 31, 2016), https://www.pbs.org/newshour/economy/china-wants-to-mine-themoon-for-space-gold [https://perma.cc/V82M-XAU3].

${ }^{101}$ In fact, based on the One Lucite Ball case, it would seem that each of the countries that received a fragment of the Goodwill Moon Rock could also claim ownership of lunar material. This includes 86 of the 107 current states parties to the Outer Space Treaty (not to mention 22 of the nonparty signatory states). If these countries do, in fact, claim ownership, this very widespread and concordant conduct becomes an excellent example of subsequent practice. (The total number of eighty-six was determined by comparing Where Today Are the Apollo 17 Goodwill Moon Rocks?, COLLECTSPACE, http://www.collectspace.com/resource s/moonrocks_goodwill.html [https://perma.cc/ZRX8-YXT3] (listing the 135 countries that received a Goodwill Moon Rock fragment) with WIKIPEDIA, supra note 71 (listing the 107 current states parties and 23 nonparty signatories to the Outer Space Treaty)). 
Another example of a space resource, the use of which is both more prevalent and more important for everyday life, is the use of Earth orbit for satellites. Since the launch of Sputnik 1 in 1957,102 Earth orbit has been filled with thousands of launched objects ${ }^{103}$ including 1,738 currently operating satellites. ${ }^{104}$ Earth orbit, especially geostationary orbit (GSO), is a limited and valuable commodity. ${ }^{105} \mathrm{GSO}$ is in such high demand that the International Telecommunication Union (ITU) ${ }^{106}$ was assigned the responsibility of managing the assignment of orbital slots in order to avoid interference between satellites ${ }^{107}$ and to ensure an equitable means of providing GSO access for all countries. ${ }^{108}$ Significantly, orbital slots are used both by governments and private entities and are used for both public and commercial purposes. ${ }^{109}$ The many years of using this system to assign orbital slots demonstrates, in spite of some controversy, ${ }^{110}$ broad international agreement that this space resource can be used by private entities, and can be used for commercial purposes.

\section{2. "Benefit" of Using Space Resources}

Some subsequent practice relates directly to the obligation to share benefits from the use of space resources. The failure of most states to sign or ratify the Moon Agreement after nearly forty years appears to be a rejection of its proposed international regime to organize the sharing of benefits from space resources. ${ }^{111}$ Nevertheless, most countries recognize an obligation to share

102 KLEIMAN, supra note 98 , at vii-viii.

103 At present there are over 8,000 space objects registered with the United Nations. Office for Outer Space Affairs, Online Index of Objects Launched into Outer Space, UNITED NATIONS, http://www.unoosa.org/oosa/osoindex/search-ng.jspx?lf_id= [https://perma.cc/CN5LW6EG].

${ }^{104}$ UCS Satellite Database, UNION OF CONCERNED SCIENTISTS, http://www.ucsusa.org/ nuclear-weapons/space-weapons/satellite-database\#.WKiMVBIrKRs [https://perma.cc/NM2 K-GSWE] (last updated Nov. 7, 2017).

105 KLEIMAN, supra note 98 , at 61 . GSO is limited because it can only be attained above the equator at a specific altitude of approximately 22,300 miles. SHAW, supra note 6, at 399 . It is valuable because it "is the only orbit capable of providing continuous contact with ground stations via a single satellite." Id.

106 The ITU was first established in 1865 to manage international telegraph networks, and its mandate has since expanded to include all manner of communication technologies. Discover ITU's History, ITU, http://handle.itu.int/11.1004/020.2000/s.031 [https://perma.cc/ R9AK-SSRT].

${ }^{107}$ KLEIMAN, supra note 98 , at 61.

108 Id. at 64 .

${ }^{109} I d$. at 59-60 ("The operation of private telecommunications satellites is, by far, the most successful, widespread, and profitable commercial use of outer space to date.").

${ }^{110} \mathrm{Id}$. at $62-68$.

${ }^{111}$ Christopher D. Johnson, Reality and Clarity in Understanding the Prohibition on National Appropriation in Article II of the Outer Space Treaty 9 at n.* (66th International Astronautical Congress, Paper No. IAC-15-D4.3.13, 2015), https://swfound.org/media/205288 
benefits from the use of space resources and many countries with active space programs claim that they satisfy that obligation by directly involving other countries in space activities or sharing information and knowledge derived from space activities with other countries.

Thirty years after concluding the Outer Space Treaty, states parties reiterated and further described the obligation for sharing benefits obtained from outer space by agreeing to the U.N. Space Benefit Declaration. ${ }^{112}$ This Declaration, adopted unanimously by resolution of the U.N. General Assembly, ${ }_{113}$ was specifically intended to "facilitat[e] the application of the principle that the exploration and use of outer space ... shall be carried out for the benefit and in the interest of all countries." 114 The resolution calls on "[a]11 States, particularly those with relevant space capabilities and with programmes for the exploration and use of outer space...to promot[e] and foster[] international cooperation [giving] particular attention ... to the benefit and the interests of developing countries and countries with incipient space programmes." 115 However, there are no specific rules laid down to determine the nature of these benefits. Rather, the resolution provides a flexible arrangement giving states the "free[dom] to determine all aspects of their participation in international cooperation in the exploration and use of outer space" provided that participation is "on an equitable and mutually acceptable basis" and "[c]ontractual terms [are] fair and reasonable." 116

Although the Declaration, as a U.N. resolution, is not binding per se, its terms are subsequent practice among the states parties to the Outer Space Treaty, and may be binding to the extent that they further express existing treaty obligations. ${ }^{117}$ Several countries with active space programs have actually

/reality-and-clarity-in-understanding-the-prohibition-on-national.pdf [https://perma.cc/Y3LELKHZ].

112 G.A. Res. 51/122, Declaration on International Cooperation in the Exploration and Use of Outer Space for the Benefit and in the Interest of All States, Taking into Particular Account the Needs of Developing Countries, at 1-2 (Feb. 4, 1997).

113 Office for Outer Space Affairs, A/RES/51/122, UNITED NATIONS, http://www.unoosa. org/oosa/oosadoc/data/resolutions/1996/general_assembly_51st_session/ares51122.html [https://perma.cc/Q7RX-57ZE].

114 G.A. Res. 51/122, supra note 112 , at 2 .

${ }^{115} \mathrm{Id}$. at annex, para. 3.

${ }^{116} I d$. at annex, para. 2 .

${ }^{117}$ Even without an existing treaty, the provisions of a U.N. resolution may become rules of international law to the extent that states agree with and conform to them. See BIN CHENG, Outer Space: The International Legal Framework-the International Legal Status of Outer Space, Space Objects, and Spacemen, in STUDiES IN INTERNATIONAL SPACE LAW 383, 391 92 (1997); SHAW, supra note 6, at 394. This evolution from U.N. resolution provision to rule of international law, if it occurs, can happen quickly. In 1965, Bin Cheng controversially suggested that due to the rapid agreement on U.N. resolutions on space law in the 1960s those resolutions may have represented "instant customary international law." BIN CHENG, The United Nations and the Development of International Law Relating to Outer Space, in StUdies In INTERNATIONAL SpaCE LAW 150, 192 (1997). However, his use of the term "instant" was intended merely to indicate the rapidity of the development and not that the 
linked their specific efforts to share benefits of using space to the Space Benefit Declaration. ${ }^{118}$ For example, Austria participates in European Space Agency "cooperation projects that especially benefit developing countries,"119 and provides "special support" 120 for individuals from developing countries to participate in education and training in space-related fields. France reports that it uses its cooperation agreements with developing countries to "foster[] the development of relevant and appropriate space capabilities."121 In 2014, the United Kingdom created the "Newton Fund" in order to "promote the economic development and welfare of developing countries" that currently has an annual allocation of $£ 75$ million. ${ }^{122}$

The United States has also publicly identified how it responds to the obligation to share benefits. In remarks before the Legal Subcommittee of COPUOS, the United States affirmed its support of the principle that the use of outer space benefit "all peoples" and asserted that the United States "remains highly engaged in activities that benefit non-space-faring nations." 123 The United States specifically cited the sharing of weather and GPS data "free of direct user fees" and the sharing of space and Earth science data "with the world scientific community" at little or no cost as responsive to this principle. ${ }^{124}$

General Assembly resolutions were legally binding. Id. at 192-93, 197 (explaining that, depending on the circumstances, "the time factor is not of crucial importance" in the formation of rules of international law, but that nevertheless " $[\mathrm{r}] \mathrm{ules}$ of international law are binding because States consider[] themselves bound by them"); Birgit Haugk et al., The Contribution of the United Nations to the Further Development of International Law-Using the Example of Outer Space Law, 2 SRI LANKA J. INT'L L. 89, 95 (1990) (describing the notion of "instant customary law" as "replac[ing] long-term practice by "intensity of practice"”).

118 These countries include Australia, Austria, France, Japan, and the United Kingdom. Comm. on the Peaceful Uses of Outer Space, Compendium: Mechanisms Adopted by States and International Organizations in Relation to Non-Legally Binding United Nations Instruments on Outer Space 2 (Mar. 31, 2017), http://www.unoosa.org/documents/pdf/spacelaw Non legallyb mech/COMPENDIUM Updated 31 March 2017.pdf [https://perma.cc/L2WD-

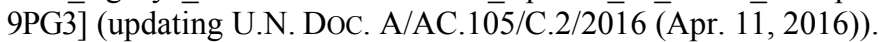

119 Id. at 9.

$120 \mathrm{Id}$. at 10 .

${ }^{121} \mathrm{Id}$. at 26 ("[The agreements typically include:] Exchange of information and data ...; [t]raining of experts, including scientists and students; [e]xchange of personnel; [o]rganization of joint workshops, seminars and symposiums; [p]romotion of space activities towards the youth.").

$122 \mathrm{Id}$. at 60 .

${ }^{123}$ COPUOS Transcript, supra note 67 , at 11 . NASA has been actively involved in working with developing countries. NAT'L AERONAUTICS \& SPACE ADMIN., RELEASE No. 11-123, NASA and USAID Pledge To AdVANCE InTERnational DeVElopment With SCIENCE AND TECHNOLOGY (Apr. 25, 2011), https://www.nasa.gov/home/hqnews/2011/apr/HQ 11-123_NASA_USAID.html [https://perma.cc/YAB3-2LNY]; NAT'L AERONATUICS \& SPACE ADmin., Release No. 10-244, NASA Hosts Symposium About Latin American SPaCe PARTNERSHIPS (Sept. 16, 2010), https://www.nasa.gov/home/hqnews/2010/sep/10-224_Latin American_Symposium.html [https://perma.cc/Y5UB-JFTT].

${ }^{124}$ COPUOS Transcript, supra note 67, at 12. 
Taken together, the subsequent practice of states parties to the Outer Space Treaty regarding the sharing of benefits from the use of outer space reinforces the Treaty obligation to share benefits with other countries. However, according to the spacefaring countries, this obligation is tempered by the right of a state using a space resource to determine how to define and distribute the benefit. This tension between a broadly accepted obligation to share and an individual state's right to determine how and what to share makes for a weak obligation and reflects the same lack of consensus around space resources that undoubtedly has kept the Moon Agreement from attaining broad acceptance.

\section{Sovereignty over Space Resources}

A critical limit on the rights of states in outer space is the prohibition on national appropriation, including by claim of sovereignty. ${ }^{125}$ This limit has been consistently followed by the international community, including the United States even when it has claimed ownership of a space resource. For example, the U.S. government planted flags on the Moon and claims ownership of the lunar material it collected. ${ }^{126}$ Nevertheless, the United States does not claim to have appropriated lunar territory. As one commentator described it, the act of planting flags on the Moon by U.S. astronauts "signified a national achievement, not the acquisition of territory." 27 Even the Space Resource Act itself declares that "the United States does not . . . assert sovereignty or sovereign or exclusive rights or jurisdiction over, or the ownership of, any celestial body," 128 while at the same time recognizing private ownership of space resources.

In the case of orbital resources, there was an attempt in 1976 by a group of equatorial nations to extend their sovereignty beyond airspace into Earth orbit claiming that geostationary orbit constituted a natural resource of their subjacent countries. ${ }^{129}$ The international community rejected this claim. ${ }^{130}$ More recently, the United States and other countries partnering to establish the International Space Station went out of their way in the cooperation agreement to declare that no portion of the space station or its use "constitut[ed] a basis for asserting a

125 Outer Space Treaty, supra note 4, art. II.

${ }^{126}$ NAT'L AERONAUTICS \& SPACE ADMIN., supra note 93, at 2.

127 Gabrynowicz \& Serrao, supra note 12, at 230; see also Simpson, supra note 12, at 179.

${ }^{128}$ U.S. Commercial Space Launch Competitiveness Act, Pub. L. No. 114-90, § 403, 129 Stat. 704, 722 (2015). Noted space law commentator Fabio Tronchetti considered it "highly significant that the U.S. . . decided to emphasize this point." Tronchetti, supra note 83 , at 149.

129 The Bogotá Declaration, WORDPRESS, https://bogotadeclaration.wordpress.com/declara tion-of-1976/ [https://perma.cc/M6HF-LT2S]; see also D. Goedhuis, Influence of the Conquest of Outer Space on National Sovereignty: Some Observations, 6 J. SpACE L. 37, 38-39 (1978).

${ }^{130}$ KLEIMAN, supra note 98, at 63-64; SHAW, supra note 6, at 399. Interestingly, there has never been a firm delimitation made as to where airspace (with sovereignty) ends and outer space (without sovereignty) begins. SHAW, supra note 6, at 393; Goedhuis, supra note 129 , at 40 . 
claim to national appropriation over outer space or over any portion of outer space" by any of the signatory countries. ${ }^{131}$

This repeated and concordant conduct by states, spread over several decades, constitutes subsequent practice by states parties to the Outer Space Treaty establishing agreement that the use or claim of ownership of a space resource by a country does not constitute a territorial claim or national appropriation of outer space, even if the exercise of sovereignty is necessary to establish or protect the use or claim of ownership.

\section{Space Resources and the Results of Subsequent Practice}

When viewed together, the subsequent practice of states before the United States passed the Space Resource Act suggests general agreement as to certain limited aspects of the rights and obligations pertaining to space resources contained in the Outer Space Treaty. The areas of agreement can be summarized as follows:

1. Mineral space resources extracted from celestial bodies can be owned by governmental entities and used for scientific, goodwill, or educational purposes. ${ }^{132}$

2. Orbital space resources can be used by both governments and private entities for commercial purposes.

3. When using space resources there is an obligation to provide some benefit to other countries, but this is flexible and to be decided by the space resource user.

4. Space resources can be used or owned without national appropriation of the portion of outer space or the celestial body where the resource is located. 133

It is interesting to note that while both orbital slots and Moon rocks qualify as space resources and fall under the auspices of the Outer Space Treaty they have been treated differently in practice. This difference is not surprising, however, considering their different characteristics. While both are limited resources, they are limited in fundamentally different ways. Orbital resources are limited in terms of how many parties can use a particular orbit at once, but this type of resource is inexhaustible. No matter how much an orbit is used, it will never be used up. Once an orbital slot is no longer used by one user, the next user will receive a fully utilizable, undiminished resource. On the other hand, mineral resources on the Moon are exhaustible just as they are on Earth.

${ }^{131}$ Agreement Concerning Cooperation on the Civil International Space Station art. 2, para. 2(c), Jan. 29, 1998, T.I.A.S. No. 12927. State parties to the agreement are Canada, Japan, Russia, the United States, and the European Space Agency member governments (Belgium, Denmark, France, Germany, Italy, the Netherlands, Norway, Spain, Sweden, Switzerland, and the United Kingdom). Id. at pmbl.

132 Tronchetti, supra note 83, at 146.

${ }^{133}$ See Galloway, supra note 24, at 312. 
If one user extracts mineral resources, later users of the Moon will not be able to use those same resources. Once extracted, the resource is gone forever.

This difference in resource type may explain the difference in how the international community has treated space resources: accepting private, commercial use of orbital resources (inexhaustible resources) but accepting only governmental use or ownership of mineral resources (exhaustible resources) for certain purposes. It is logical that questions of equity and fairness will be most keenly at issue where a resource is subject to depletion as opposed to one that can be used repeatedly without any depletion. As a result, it is clear that there is no agreement at present, among the parties to the Outer Space Treaty, that a private entity can use or own exhaustible space resources for commercial purposes. ${ }^{134}$

\section{The SpaCe Resource ACT}

The Space Resource Act is a brief statute ${ }^{135}$ that purports to recognize private ownership of space resources. ${ }^{136}$ The Act says a U.S. citizen can "possess, own, transport, use, and sell [an] asteroid resource or space resource." 137 However, the rights are only recognized if the resource is "obtained in accordance with ... the international obligations of the United States." 138 What are the international obligations applicable to these rights?

\section{A. Compliance with the Outer Space Treaty}

There is widespread agreement that the Outer Space Treaty is the primary international obligation at issue here. Congressional consideration of the law

134 JoHnsON, supra note 111, at 9. There also appears to be no agreement that governments can use exhaustible space resources for commercial purposes. But see Douglas Martin, Space Artifacts of Soviets Soar at a $\$ 7$ Million Auction, N.Y. TIMES (Dec. 12, 1993), http:/www.nytimes.com/1993/12/12/nyregion/space-artifacts-of-soviets-soar-at-a-7-million-auctio n.html (on file with Ohio State Law Journal) (reporting that the Russian government sold three moon rocks at auction (presumably to private buyers) for $\$ 442,500$ ).

135 Space Resource Exploration and Utilization Act of 2015, Pub. L. No. 114-90, $\S \S 401-403,129$ Stat. 704, 720-22 (2015) (to be codified at 51 U.S.C. $\S \S 51301-51303$ ). The Space Resource Act takes up less than two pages of the larger U.S. Commercial Space Launch Competitiveness Act. Id.

136 The full text of the Space Resource Act provision related to space resource rights reads as follows:

A United States citizen engaged in commercial recovery of an asteroid resource or a space resource under this chapter shall be entitled to any asteroid resource or space resource obtained, including to possess, own, transport, use, and sell the asteroid resource or space resource obtained in accordance with applicable law, including the international obligations of the United States.

Id. $\S 403$ (to be codified at 51 U.S.C. $\S 51303$ ).

${ }_{137}$ Id.

${ }^{138}$ Id. (emphasis added). 
made specific reference to the Treaty, ${ }^{139}$ and commentators refer to this Treaty when discussing the law in the context of space resources. ${ }^{140}$ Even industry advocates who support the law do not dispute that the Outer Space Treaty applies. ${ }^{141}$ In fact, in a presentation to the Legal Subcommittee of COPUOS, a representative of U.S. private sector space interests made the point unequivocally: "[W]e in the private sector worked diligently with our colleagues on Capitol Hill to ensure that the [Space Resource Act] complied with and supported the Outer Space Treaty." 142

In spite of this agreement, there are differences of opinion as to whether the Space Resource Act violates the Outer Space Treaty. Some claim a potential violation of the Outer Space Treaty based on the Treaty's requirement that all countries must benefit from the use of outer space, or because the prohibition on claims of sovereignty on celestial bodies means that domestic law cannot recognize property rights in space resources obtained from asteroids or the Moon. ${ }^{143}$ Others, especially industry advocates, claim the Act does not violate the Outer Space Treaty because the Treaty contains no specific prohibition on ownership of space resources ${ }^{144}$ and leaves it to each state party to determine how to share the benefits of space resources. ${ }^{145}$ There are also arguments that

139161 CONG. REC. H8196 (daily ed. Nov. 16, 2015) (statement of Rep. Posey). It is also worth noting that the title of the Act uses the phrase "Exploration and Utilization," which mirrors the phrasing ("exploration and use") used in Article I of the Outer Space Treaty.

${ }^{140}$ See, e.g., Position Paper on Space Resource Mining, InT'L INST. SPACE L. 3 (Dec. 20, 2015), http://iislwebo.wwwnlss1.a2hosted.com/wp-content/uploads/2015/12/SpaceResource Mining.pdf [https://perma.cc/3DUK-JMCJ] (discussing the Space Resource Act and international space law).

${ }^{141}$ E.g., BUS. L. BASICS, supra note 19; Sagi Kfir, Is Asteroid Mining Legal?, DEEP SPACE INDUSTRIES, http://deepspaceindustries.com/is-asteroid-mining-legal/ [https://perma.cc/ HR9T-ZNFG].

142 Committee on the Peaceful Uses of Outer Space: Legal Subcommittee, 56th Session, U.N. OFF. FOR OUTER SPACE AFF., at 143:01 (Mar. 29, 2017) (technical presentation by Mike Gold, Chair, Commercial Space Transportation Advisory Committee (COMSTAC)), https://icms.unov.org/CarbonWeb/public/oosa/speakerslog/c621aa64-f029-44d5-8456-d28 $75 \mathrm{fa} 0 \mathrm{~d} 4 \mathrm{~cd}$ (on file with Ohio State Law Journal) [hereinafter COPUOS Mar. 29]. COMSTAC is the official advisory committee to the U.S. Federal Aviation Administration Office of Commercial Space Transportation. See Office of Commercial Space Transportation: Commercial Space Transportation Advisory Committee (COMSTAC), FED. AVIATION ADMIN., https://www.faa.gov/about/office_org/headquarters_offices/ast/advisory _committee/ [https://perma.cc/89SJ-YU92].

143 Tronchetti, supra note 83, at 145-46.

${ }^{144}$ See, e.g., Kfir, supra note 141; Frans von der Dunk, The US Space Launch Competitiveness Act of 2015, JURIST (Nov. 30, 2015), http://www.jurist.org/forum/2015/11/ frans-vonderdunk-space-launch.php [https://perma.cc/8Q53-TJJH].

${ }^{145}$ Galloway, supra note 69 , at 26 (recounting the U.S. Senate's understanding "that nothing in article I, paragraph 1 of the [Outer Space Treaty] diminishes or alters the rights of the United States to determine how it shares the benefits and results of its space activities"). For purposes of U.S. law, it is also important to understand if the Treaty is selfexecuting. In general, a treaty is considered to be self-executing if it can "be enforced in the courts without prior legislation by Congress, and [is] non-self-executing . . . [if it can]not be 
some asteroids, due to their small size, should not even be considered "celestial bodies" thereby allowing them to be claimed as a resource in their entirety. ${ }^{146}$

While both sides have valid points, the best interpretation is likely somewhere in between. Detractors of the Space Resource Act properly assert that the Outer Space Treaty clearly prohibits countries from appropriating outer space, ${ }^{147}$ and their argument that recognition of property rights amounts to appropriation by exercise of sovereignty is compelling. However, the subsequent practice described in Part III shows that countries have accepted that governments may claim ownership of Moon rocks ${ }^{148}$ while not appropriating the Moon itself. If this is the case, then countries are willing to accept a distinction between recognizing ownership of extracted space resources and national appropriation of the territory that produced the resources. ${ }^{149}$ Indeed,

enforced in the courts without prior legislative 'implementation." Carlos Manuel Vázquez, The Four Doctrines of Self-Executing Treaties, 89 AM. J. INT'L L. 695, 695 (1995). Although this issue has not been adjudicated in U.S. courts with regard to the Outer Space Treaty specifically, portions of the Treaty could be considered self-executing because they do not require any legislative action. For example, the freedom to explore outer space requires no implementation by the government and therefore is automatically enforceable. Other elements, such as the ability of nongovernmental parties to conduct activities in outer space, require authorization by the government and would, therefore, be non-self-executing. Meredith Blasingame, Comment, Nurturing the United States Commercial Space Industry in an International World: Conflicting State, Federal, and International Law, 80 Miss. L.J. 741,775 (2010). But see Tronchetti, supra note 83, at 149. This means that obligations in non-self-executing provisions of the Treaty can be met in many ways based on the particular needs and interests of the state. See Bin Cheng, Article VI of the 1967 Space Treaty Revisited: "International Responsibility", "National Activities", and "the Appropriate State," $26 \mathrm{~J}$. SPACE L. 7, 14 (1998) (noting, for example, that where multiple states may have a responsibility to authorize an activity, "it is possible [for them] to arrange for one of them to carry out this function").

146 See Bus. L. BASICS, supra note 19.

${ }^{147}$ See Trevor Bach, Obama's New Push To Mine Outer Space Could Spark a Disaster, Miami Professor Warns, MiAmi New TIMES (Dec. 10, 2015), http://www.miaminewtimes.com/ news/obamas-new-push-to-mine-outer-spacecould-spark-a-disaster-miami-professor-warns-81053 84 [https://perma.cc/DF5E-B37N].

${ }^{148}$ One might debate whether it is ownership or mere use of Moon rocks that is generally recognized. However, using the United States as an example, the United States' generally accepted "use" of Moon rocks seems indistinguishable from ownership because of the way it exercises exclusive control over them. As two space lawyers put it: "Under any definition of ownership, the United States clearly owns the Apollo lunar samples. Any entity that can claim something as an exclusive resource, control its transport and distribution, and can exchange it for something else of value (in this case, other lunar samples), clearly owns that object." Berin Szoka \& James Dunstan, Space Law: Is Asteroid Mining Legal?, WIRED (May 1, 2012), https://www.wired.com/2012/05/opinion-asteroid-mining/ [https://perma.cc/K3BQ$7 \mathrm{KMF}$.

${ }^{149}$ Numerous commentators support this distinction. E.g., Doyle, supra note 76, at 114 (arguing that "[t]he inability to declare sovereignty is no constraint upon use"); Johnson, supra note 111, at 4 (arguing that "[t]here is a significant distance between a national government extending its territory onto large celestial planets [and] missions which extract 
this is a logical result where states parties are attempting to implement a Treaty that contains an apparent contradiction between the simultaneously applicable right to use outer space and the prohibition against national appropriation of outer space.

Supporters of the law are correct in asserting that there is no specific prohibition on space resource ownership in the Outer Space Treaty. ${ }^{150}$ Also, the fact that the Moon Agreement did propose such a prohibition ${ }^{151}$ and then was not accepted by most countries ${ }^{152}$ is a compelling argument that countries have rejected the idea of a prohibition. However, just because countries did not agree to a prohibition does not mean that private ownership of space resources was accepted. Even though most countries did not ratify the treaty, it was adopted by consensus of all members of the United Nations. ${ }^{153}$ Plus, the repeated statement of the need for the use of outer space to benefit all countries that appears in the Outer Space Treaty (1967), the Moon Agreement (1979), and the Space Resource Declaration (1997) militates against a categorical assertion that international law currently supports private space resource ownership.

In addition, U.S. legal precedent on the matter also urges caution. In a rare U.S. court case applying the Outer Space Treaty to the question of private property interests, a federal district court determined that the Treaty itself did not "create[] any rights in [the Plaintiff, a private individual] to appropriate private property rights on asteroids." 154 While not foreclosing the possibility of private property rights in space resources, this case establishes that, as far as U.S. law is concerned, the Treaty created no inherent right to private property in space. This implies that under the Outer Space Treaty, private ownership of

resources from asteroids for scientific and commercial purposes, especially if those missions are [conducted] in the spirit of space activities which the Outer Space Treaty contemplates").

150 Tronchetti, supra note 83 , at 146 .

${ }^{151}$ Moon Agreement, supra note 8, art. 11, para. 3 ("Neither the surface nor the subsurface of the moon, nor any part thereof or natural resources in place, shall become property of any State, international intergovernmental or non-governmental organization, national organization or non-governmental entity or of any natural person.") This prohibition was only to last until a proposed international regime "to govern the exploitation of the natural resources of the moon" was established. Id. art. 11, para. 5.

${ }^{152}$ See Simpson, supra note 12, at 181 (noting, in 2014, the difficulty of advocating the effectiveness of the Moon Agreement "when most of the world's countries have not accepted an opportunity to endorse it in the nearly thirty-five years since [it] was first open for signature"); supra note 11.

153 The text of the Moon Agreement was adopted by unanimous consent as General Assembly Resolution 34/68. See Voting Record Search: A/RES/34/68, UnITED NATIONS BIBLIOGRAPHIC INFO. SYS., http://unbisnet.un.org:8080/ipac20/ipac.jsp?session=14874864908T H.11201\&profile=voting\&uri=full=3100023 !856627 !1\&ri=1\&aspect=power\&menu=search\&s ource $=\sim$ !horizon [https://perma.cc/5QZY-M48N].

${ }^{154}$ Nemitz v. United States, No. CV-N030599-HDM (RAM), 2004 WL 3167042, at *2 (D. Nev. Apr. 26, 2004), aff'd, 126 Fed. App'x 343 (9th Cir. 2005). This determination was made notwithstanding the "failure [of] the United States to ratify the [Moon Agreement]." Id. 
space resources requires recognition by a state, which the Space Resource Act purports to do.

Unfortunately, this debate just demonstrates the lack of certainty about the nature of space resource rights and obligations under international law. And since the international obligations with regard to space resources are not well defined, the language of the Space Resource Act simply imports the unclear legal status of such resources into domestic law. ${ }^{155}$

\section{B. Promoting Subsequent Practice}

In addition to being part of U.S. domestic law, the Space Resource Act is potentially part of the United States' own subsequent practice relative to the Outer Space Treaty. This makes the Space Resource Act a tool the United States can use to influence international law by encouraging sustained, concordant conduct by other countries. ${ }^{156}$ So far, however, there have been mixed reactions to the U.S. law.

Soon after passage of the U.S. Space Resource Act, Luxembourg announced plans, in line with the U.S. action, to create a "formal legal framework which ensures that private operators working in space can be confident about their rights to the resources they extract." 157 Luxembourg subsequently finalized a new law, which begins with the following declaration: "Space resources are capable of being appropriated." 158 This is potentially an even broader recognition of ownership rights than in the United States because, unlike the Space Resources Act, it does not limit recognition of the appropriation to citizens of Luxembourg.

While the Luxembourg action is concordant with the U.S. approach to space resources, other countries have expressed clear reservations about the approach

${ }^{155}$ See von der Dunk, supra note 69, at 14 (describing how, due to lack of an authoritative interpretation of obligations within the Outer Space Treaty, "uncertainties existing on the international level [may] be transposed also to the national level, causing legal uncertainty with any prospective private entity interested in undertaking space activities").

${ }^{156}$ See id. ("[U]ltimately it is up to the states concerned to create the state practice and opinio juris which could lead to authoritative interpretations [of Outer Space Treaty obligations]."); Position Paper on Space Resource Mining, supra note 140 (arguing that the Space Resource Act can be a "starting point for the development of international rules").

${ }^{157}$ Initiative, SPACERESOURCES.LU, http://www.spaceresources.public.lu/en/index.html [https://perma.cc/LCF9-EBDX].

${ }^{158}$ Draft Law on the Exploration and Use of Space Resources, SPACERESOURCES.LU, art. 1 (2017), http://www.spaceresources.public.lu/content/dam/spaceresources/news/Translation \%20Of\%20The\%20Draft\%20Law.pdf [https://perma.cc/F476-3RSM] (Lux.) (translating Luxembourg law). The authoritative version of this provision in French is the same: "Les ressources de l'espace sont susceptibles d'appropriation." Loi 674 du 20 juillet 2017 sur l'exploration et l'utilisation des ressources de l'espace [Law 674 of July 20, 2017 on the Exploration and Use of Space Resources], JOURNAL OfFICIEL DU GRAND-DUCHE DE LUXEMBOURG, July 28, 2017, art. 1, http://legilux.public.lu/eli/etat/leg/loi/2017/07/20/a674/jo [https://perma.cc/6XX4-KCCE]. 
taken by the United States and Luxembourg. During the meeting of the Legal Subcommittee of COPUOS in March and April 2017, several countries expressed concern about possible "gaps or contradictions in the [international] legal framework" if the ability to exploit space resources is determined by national laws. ${ }^{159}$ Others were concerned about the sharing of benefits ${ }^{160}$ and the possibility of international conflict around space resources ${ }^{161}$ unless the issue was resolved through international mechanisms. There was also disagreement among participants regarding the role of private commercial entities in the use of space resources. ${ }^{162}$

It is worth noting that the United States specifically recognized the lack of agreement on the issue of space resources when its representative said, "Our own national view is that the legal issue [of space resources] is relatively straightforward, but that's obviously not shared by everyone, ... and we do think that we should continue to discuss this." 163 However, while recognizing

159 Committee on the Peaceful Uses of Outer Space: Legal Subcommittee, 56th Session, U.N. OFF. FOR OUTER SPACE AFF., at 89:33 (Mar. 28, 2017), https://icms.unov.org/Carbon Web/public/oosa/speakerslog/ecdbee63-c7d8-4267-a070-34155faed934 (on file with Ohio State Law Journal) [hereinafter COPUOS Mar. 28] (remarks by delegate from Costa Rica on behalf of the G77 and China).

${ }^{160} I d$. at 90:25 (remarks by delegate from Costa Rica) ("The G77 and China considers that, besides the need for a broad debate about the implications of these activities, the developing countries shall not be excluded from the benefits of space exploration and their rights should be considered in the discussion."); COPUOS Mar. 29, supra note 142, at 69:26 (remarks by delegate from Chile, simultaneous translation in English) ("[T]his specific subject - space mining - should only be in the interest of all countries; and that implicitly and clearly means that this would be something carried out on an equal footing."); COPUOS Mar. 29, supra note 142, at 79:13 (remarks by delegate from Morocco, simultaneous translation in English) ("[W]e think that an international legal model on the exploitation and use of space resources could be envisaged because this would enable us, in particular, to [better guarantee] the interests of developing countries and other guarantees as well relating to the fundamental principles of space.").

${ }^{161}$ COPUOS Mar. 29, supra note 142, at 59:23 (remarks by delegate from Brazil) ("Brazil expresses its concern with the view that this matter can be effectively regulated by means of individual, unilateral, domestic initiatives that aim to regulate commercial activities in outer space. If this trend is confirmed, we are likely to see the development of multiple, incompatible frameworks, a situation that is prone to lead to conflict and that may eventually affect the sustainability of outer space.").

162 Compare COPUOS Mar. 28, supra note 159, at 95:11 (remarks by delegate from China, simultaneous translation in English) ("China believes that, based on ... the Outer Space Treaty, countries, including private entities that are approved and supervised by these countries, have the right to conduct activities in exploration and utilization of outer space and the use of space resources."), with COPUOS Mar. 29, supra note 142, at 60:30 (remarks by delegate from Brazil) ("Even though some countries support the view that existing international space law does not prohibit private commercial activities in celestial bodies, it is also true that the U.N. space treaties do not authorize such activities, particularly exploitation. And, indeed, a stronger case can be made to support this latter view.").

${ }^{163}$ COPUOS Mar. 29, supra note 142, at 110:24 (remarks by delegate from the United States). 
the need for additional discussion in COPUOS, the United States deliberately noted that the terms of the Outer Space Treaty could not be interpreted by COPUOS but only by the states parties to the Treaty. 164 Given this ongoing debate, it is clear that the Space Resource Act does not yet represent an agreed interpretation of the Outer Space Treaty as it pertains to private entities and space resources.

It may still be possible for the United States to establish such agreement. However, since some countries have already raised objections to the U.S. law, ${ }^{165}$ they and others will likely reject approaches to implement the Space Resource Act that appear to be self-serving or in blatant disregard to the Outer Space Treaty's overall purpose to promote peace and cooperation in the exploration and use of outer space. To overcome existing objections and establish agreement among the parties, the United States will need to implement the law in a way that reflects a good-faith interpretation of the Treaty's obligations. As discussed in Part II, there are three elements to determining whether a treaty interpretation has been made in good faith. The first is the interpretation's reasonableness. Second is the balancing of the rights of the parties and avoiding abuse of the interpreting party's position. Third is the ability to give effect to all the treaty provisions. The following discussion proposes a good-faith interpretation of the Outer Space Treaty based on these elements.

First, consider again the basic rights and obligations regarding space resources and private entities as set out in the Outer Space Treaty. Article 1 says that "[o]uter space ... shall be free for exploration and use by all States," 166 but it also says that exploration and use "shall be carried out for the benefit and in the interests of all countries, irrespective of their degree of economic or scientific development." 167 It could be argued that the mere use of space resources provides general benefits to humanity (and, presumably, all countries as a result) in compliance with the Outer Space Treaty by expanding the availability of resources that are scarce on Earth and promoting technological development. ${ }^{168}$ However, this is a weak argument since benefits would accrue

${ }^{164} \mathrm{Id}$. at 115:48 (remarks by delegate from the United States) ("I also wanted to just go on record and recognize that the Legal Subcommittee does not have a mandate to offer definitions of treaty terms. The appropriate actors to interpret terms within a treaty are the state parties, so that's just a fundamental reality of international law.... [W]e don't think it's appropriate as a general matter for this body to take on a specific role in defining particular terms ....”).

165 Significant objections were raised even before the 2017 COPUOS Legal Subcommittee meeting. E.g., Jeff Foust, Mining Issues in Space Law, SpACE REV. (May 9, 2016), http://www.thespacereview.com/article/2981/1 [https://perma.cc/VFH6-6BRK] (recounting Russian statements that the Space Resource Act is "inconsistent with ... international obligations" and "undermines the international legal regime").

166 Outer Space Treaty, supra note 4, art. I, para. 2.

${ }^{167} I d$. art. I, para. 1.

168 See Galloway, supra note 69, at 31 (mentioning different attitudes toward the sharing of benefits). 
in this way equally well without the Outer Space Treaty. Therefore, a reasonable interpretation of the Treaty must assume that by specifying the spreading of benefits in the Outer Space Treaty, the states parties must have intended a spreading of benefits other than what would have occurred without the Treaty.

Second, the Outer Space Treaty's explicit recognition of a difference in the "degree of economic [and] scientific development"169 among countries points to an understanding that not all countries are themselves able to directly benefit from outer space being "the province of all mankind." 170 If a country is unable to build and launch rockets or create the technology to explore and use outer space, then outer space being the province of all mankind becomes a hollow sentiment, devoid of practical meaning to those who are not able to take advantage of it. The fact that the United States currently has private entities capable of engaging in commercial enterprises in outer space puts the United States in an advantageous position. ${ }^{171}$ The United States could exploit that position by, for example, mining as much space resource material as possible while other countries are still developing the technical capacity to do so. However, this would clearly be an abuse of its position. Instead, the United States has an obligation to balance its rights under the Treaty with those of the other parties, which could take the form of providing a benefit to other countries that are not currently in a position to directly obtain space resources themselves.

Third, the sharing of benefits would also satisfy the need to give effect to all the treaty terms. A unilateral exploitation of outer space would essentially make the phrase "benefit ... all countries" and related expressions ineffective because it would limit the benefits of space use to only those countries with space capabilities. Also, assuming that unilateral exploitation would engender opposition from those countries that do not benefit, such an approach would run counter to the obligation to undertake space activities "in the interest of maintaining international peace and security and promoting international cooperation and understanding." 172 Therefore, sharing of benefits must be integral to a good-faith interpretation of the Outer Space Treaty's obligations.

\section{Using the Space Resource Act To Define Outer Space Treaty OBLIGATIONS}

What approaches could the United States take to implement (or modify) the Space Resource Act in line with a good-faith interpretation of the Outer Space

169 Outer Space Treaty, supra note 4, art. I, para. 1.

170 Id.; supra Part III.B (discussing the term "province of all mankind").

${ }^{171}$ See Colin Dwyer \& Geoff Brumfiel, WATCH: SpaceX Successfully Launches Most Powerful Rocket in Decades, NPR (Feb. 6, 2018), https://www.npr.org/sections/thetwoway/2018/02/06/583627592/watch-live-spacex-attempts-launch-of-powerful-falcon-heavyrocket [https://perma.cc/N78Q-UMVG].

172 Outer Space Treaty, supra note 4, art. III. Given the opposition already expressed by members of COPUOS, the potential for a negative impact on international peace and cooperation is very possible. See supra notes $159-62$. 
Treaty's obligations? Before considering specific approaches, it is helpful to keep in mind that there are practical, not just legal, reasons for making a goodfaith interpretation. First, the more generous the United States is in interpreting its obligations, the more likely other countries will be to agree to the interpretation thereby arriving more quickly at a clear legal framework that supports private enterprise in the United States. Second, because all parties to the Treaty, not just the United States, apply the same treaty terms, any agreed interpretations resulting from U.S. practice will be applicable to all the other countries too. Since other countries may not be far behind the United States in developing off-planet missions, the United States should be careful to only promote treaty interpretations that it wants applied to others as well. ${ }^{173}$ Finally, by applying the Treaty in good faith, the United States will generate international goodwill that may prove beneficial to both the country in its international relations and its businesses in terms of allowing, even promoting, international trade in space resources.

With this in mind, the following sections present a variety of approaches to implementing the Space Resource Act in the context of a licensing or permitting process. These approaches range on a spectrum from minimal government involvement and maximum private-sector flexibility, to primarily government directed with simplified private sector responsibilities. They will be presented in roughly this order. The approaches are not necessarily mutually exclusive; it may be possible to provide several options for a license applicant to choose from. After each description, there is a discussion of potential positive and negative aspects of the approach. The one constant for all approaches is a desire for each approach to clearly satisfy the spirit of the Outer Space Treaty's obligations and encourage other countries to express their agreement with the approach. While each has a chance to succeed in this regard, the more aggressive approaches will likely produce better results, although they may be more difficult to achieve.

\section{A. Enterprise-Driven Declaration of Benefits}

Since the Space Resource Act specifies that space resource use and ownership must be in accordance with international obligations, at a minimum an applicant for a license ${ }^{174}$ to obtain space resources should be required to explain how its activities will satisfy the international obligation to

173 See supra Part III. China, in particular, appears to be poised to reach the Moon and begin a program of mining its resources. The United States should consider what kind of international standards it wants applied to China and other countries and then follow those standards.

${ }^{174}$ Paul Stephen Dempsey, National Laws Governing Commercial Space Activities: Legislation, Regulation, \& Enforcement, 36 Nw. J. INT'L L. \& BUS. 1, 19 (2016) (describing licensing as "the bedrock of governmental regulation of commercial space activities," and noting its role in "fulfill[ing] State obligations under international law"). 
"benefit...the interests of all countries."175 This would be part of the application and review process established by federal agencies, such as the one used for the Moon Express application. ${ }^{176}$ To be meaningful, some level of specificity would be necessary, including exactly what benefit would be conveyed and who would be receiving it. For example, in a request for asteroid mining, an applicant might specify that a certain amount of the mined resource, or a certain percentage of the profit of the particular activity, would be given to a particular group of countries or an international organization that provides benefits to certain countries other than the United States.

This approach would make it clear there is a consideration of Outer Space Treaty obligations in the process, and, while the requirement is minimal, it can be used to encourage future conversations about what actions are sufficient to meet the obligations. This approach is simple in that it is an administrative action and could potentially be undertaken without additional legislation since the existing law already requires compliance with international obligations. Also, by minimizing government involvement and leaving specifics to the creativity of the private sector, this approach may produce some useful innovations by the private-sector applicants that could later be developed by the government into a more formal program, perhaps one similar to those contemplated in the Subparts below.

On the negative side, this approach shifts the burden to the license applicant and still leaves unclear what actions will satisfy the Outer Space Treaty. It is possible that such an approach would be internationally viewed as the United States shirking its responsibility by shifting it to the private sector. Also, the private sector tends to prefer legal certainty, especially where investment cost is so high. ${ }^{177}$ As a result, this option may not be an improvement over the situation as it exists under current law.

175 Outer Space Treaty, supra note 4, art. 1.

176 The Federal Aviation Administration (FAA) is the lead agency responsible for reviewing applications for launch of a payload in accordance with 14 C.F.R. $\S 415.14$ C.F.R. $\S \S 415.7,415.51-.61$ (2015); FED. AVIATION ADMIN., supra note 27. In particular, the FAA conducts a payload review, and then consults with other federal agencies to determine if launching the payload "would present any issues affecting public health and safety, safety of property, U.S. national security or foreign policy interests, or international obligations of the United States." Id. However, the current process may not be adequate going forward. The FAA noted that "[f]uture missions may require additional authority to be provided to the FAA to ensure conformity with the Outer Space Treaty." Id. In fact, the President's Office of Science and Technology provided Congress with a proposal to make the review and approval process more applicable to new types of missions; however, no action has been taken to date. Letter from John P. Holdren, Dir. \& Assistant to the President for Sci. \& Tech., to Chairman Thune \& Chairman Smith, Chairmen of the Commerce, Sci., \& Transp. Comm. 4, 6-7 (Apr. 4, 2016), https://obamawhitehouse.archives.gov/sites/default/files/microsites/ostp/ csla_report_4-4-16_final.pdf [https://perma.cc/GG8X-VJC6].

${ }^{177}$ See GANGALE, supra note 26, at 51-52; supra note 19. 


\section{B. Direct Participation Requirement}

Rather than placing the entire burden on the applicant, the government could create a more directed, but still flexible framework that translates the obligations of the Outer Space Treaty into specific requirements while still allowing applicants to determine the details of how to satisfy the requirements. Such a framework could be modeled on existing preference programs for government contracts. ${ }^{178}$ For example, the federal government requires at least $10 \%$ of funds in certain transportation programs to be spent on contracts with disadvantaged business enterprises (DBEs). ${ }^{179}$ This is in response to specific findings made by Congress about the need for the program and its ongoing usefulness. ${ }^{180}$ Similarly, Congress could establish findings that clarify how it understands the United States' obligations under the Outer Space Treaty, and then establish minimum requirements for the participation of certain developing countries. For example, Congress could find that Outer Space Treaty obligations would be met if space resource activities directly benefit certain countries: countries without their own space capabilities, ${ }^{181}$ less developed countries based on criteria published by the United Nations, ${ }^{182}$ or countries identified by other criteria deemed appropriate by Congress. ${ }^{183}$

Under such a framework, for example, the U.S. government could designate a list of certain developing countries, a certain number of which must be participants in the applicant's activity at a certain minimum aggregate level of participation. The framework could establish different ways in which the country or countries must be involved to ensure benefits accrue directly to them, such as including the country as a direct investor in the resource enterprise, or employing nationals or companies from the country. For example, using the DBE model, Congress could identify a list of twenty eligible countries and

${ }^{178}$ For example, the U.S. Department of Transportation administers a disadvantaged business enterprise (DBE) program. U.S. Dept. of Transp., Disadvantaged Business Enterprise (DBE) Program, TRANSPORTATION.GOV, https://www.transportation.gov/civilrights/disadvantaged-business-enterprise [https://perma.cc/6EE8-EXH8] (last updated Feb. 17, 2016). Similarly, the State of Ohio has a preferential purchasing policy that favors domestic products. OHIO DeP'T OF ADMIN. Servs., StATE OF OHIO Procurement HANDBOOK FOR SUPPLIES AND SERVS. 43 (2007), https://procure.ohio.gov//pdf/pur_procmanual. pdf [https://perma.cc/7ST5-KRZE] ("Buy America" and "Buy Ohio" programs).

${ }^{179}$ Fixing America's Surface Transportation (FAST) Act, Pub. L. No. 114-94, $\S 1101(\mathrm{~b})(3), 129$ Stat. 1312, 1324 (2015).

${ }^{180}$ Id. $\S 1101(\mathrm{~b})(1)(\mathrm{B})$.

181 G.A. Res. 51/122, annex, 93 (Feb. 4, 1997) (requesting states "with relevant space capabilities ... [to give particular attention to] developing countries and countries with incipient space programmes").

182 E.g., Human Development Index, United Nations Dev. Programme, http:/hdr.undp.org/en/content/human-development-index-hdi [https://perma.cc/2NHM-4Z4K].

183 The United States could target, or exclude, particular countries to satisfy a variety of policy objectives. However, the requirement to benefit "all countries" should constrain this to some degree. 
require that at least five must be participants in a space resource activity and that $10 \%$ of the overall expenditures for that activity must be spent on contracts with companies from the selected eligible countries.

An advantage to this approach is the flexibility it provides to the applicant to negotiate with specific beneficiaries and determine how they would benefit. The direct participation of countries in the applicant's space resource enterprise may generate long-term relationships between U.S. businesses and businesses in other countries, and would have the potential to build capacity within the benefiting countries for producing or utilizing the technology or the resources included in the arrangement. This would have a lasting benefit for both countries even after the particular project ends.

In addition, this type of approach could also promote innovation in crafting arrangements to transfer benefits. This would be similar to the Xprize, which establishes a specific target and then leaves it to private enterprise to figure out how to achieve the target. ${ }^{184}$ Why should technology be the only area where innovation happens? Administrative issues could undoubtedly benefit from this type of innovation-driven approach as well. Compared to the Enterprise-Driven Declaration of Benefits, this approach would better ensure that benefits flow directly to developing countries, the private sector would have more clarity on what it must do to satisfy international law, and the spirit of the obligations in the Outer Space Treaty would be more clearly fulfilled.

A challenge to this approach would be verifying that nationals or companies are from the targeted country, and that their inclusion in the project would truly benefit that country. This may require a significant government administrative process to ensure contracts are truly going to nationals and companies of the eligible countries. ${ }^{185}$ There also would be costs to the applicants for negotiating and contracting for the necessary arrangements and for the ongoing management of contracts for the life of the project. In addition, this type of program would require additional legislation and additional administrative oversight beyond the existing licensing process.

\section{Space Resource Trust}

Rather than requiring an applicant to obtain the direct participation of eligible beneficiary countries, an alternative approach would be to require the applicant to instead set aside a payment that would be directed to such beneficiaries. To accomplish this, an applicant would be required to set up a

${ }^{184}$ What Is an Xprize?, XPRIZE, http://www.xprize.org/about/what-is-an-xprize [https://perma.cc/6HGW-3FAF] (describing Xprize competitions as "[s]olution-agnostic, defining the challenge and incentivizing teams around the world to find the most effective solutions").

${ }^{185}$ See, e.g., Unified Certification Program, OHIO DEP'T TRANSP., http://www.dot.state. oh.us/Divisions/ODI/SDBE/Pages/UCP.aspx [https://perma.cc/F8FU-QDBH] (providing the forms and instructions to qualify for the DBE program in Ohio). 
space resource trust. This would be an irrevocable trust ${ }^{186}$ for the benefit of particular countries or an international organization whose purpose is to benefit particular countries. This type of arrangement would allow the applicant to obtain, use, or sell the resources on its own, without the participation of other parties, with a certain required share of the value of the resources (or profits, or some similar measure) being deposited in trust for the beneficiary countries.

One advantage of this approach for applicants is eliminating the need (and cost) of negotiating and managing an arrangement with particular countries or organizations. It would be easier to simply pay a mineral extraction royalty, or some other type of payment, into a trust as the entirety of the applicant's obligation. This approach could be used as an alternative to the Direct Participation Requirement in situations where targeted countries are either not able or willing to participate in the enterprise, or the potential businesses or employees are not sufficiently qualified to meet the applicant's needs.

Another advantage includes protection of assets from direct political interference. Once set up in accordance with law, the trust would be privately managed so payments and beneficiaries would not be subject to political meddling the way a government program might be. There might also be the side benefit of space resource trusts developing into a new subsector of the trust industry as some professional trustees would develop connections with potential beneficiary organizations and countries and make the trust set-up process easier for potential applicants. In terms of meeting the obligations of the Outer Space Treaty, this approach has the potential to result in a lasting legacy for developing countries. For this to happen, the trusts would need to be recognized as charitable trusts, or some other type of perpetual trust. Also, at least some part of the corpus of the trust would need to be protected, with beneficiaries receiving funds primarily from the earnings of the trust.

Given the high investment costs associated with space resource activities, the amount of any required payment would need to be carefully considered so as not to stifle the nascent space resource industry. However, mineral extraction payments are common, ${ }^{187}$ and there are ways to structure such a requirement to be fair across different types of activities and resources. For example, a progressive rate system could be used, similar to the U.S. income tax code, to

186 Irrevocable Trust, INVESTOPEDIA, http://www.investopedia.com/terms/i/irrevocabletrust. asp [https://perma.cc/XK5H-B2QB] (“An irrevocable trust can't be modified or terminated without the permission of the beneficiary. The grantor, having transferred assets into the trust, effectively removes all of [its] rights of ownership to the assets and the trust.").

${ }^{187}$ For example, Ohio collects a severance tax on the extraction of a variety of mineral resources such as clay, limestone, salt, coal, and oil, which produced almost \$27 million in fiscal year 2015. OHIO DEP'T OF TAXATION, 2015 ANNUAL REPORT 112, http://www.tax.ohio. gov/Portals/0/communications/publications/annual_reports/2015_annual_report/2015_AR_Sectio n_2_Severance_Tax.pdf [https://perma.cc/7Y66-FXS3]. The federal government requires payments in the form of royalties, rentals, and bonuses for the extraction of resources from federal lands. Energy and Minerals, BuREAU LAND MGMT., https://web.archive.org/web/2016 0305050841/https://www.blm.gov/es/st/en/prog/energy.html [https://perma.cc/K2SR-5L57]. 
help ensure that start-ups or small businesses would not pay a disproportionately large amount relative to their profits. ${ }^{188}$

For applicants, a disadvantage of this approach would be the initial cost to set up the trust, the need to identify beneficiaries, and perhaps the possibility of future legal questions as the settlor of the trust; however, ongoing costs to manage the trust would be paid out of the revenues of the trust itself. Another potential difficulty might result if applicants end up only selecting a few countries repeatedly as beneficiaries, which would undercut the idea that the space resources should benefit all countries. The government may need to specify that there be a minimum number of beneficiary countries, or a maximum percentage benefit any one beneficiary can receive. Another variation would be to require that beneficiaries must be changed periodically. Although the contributions to the trust would be irrevocable, the applicant could retain a special power of appointment ${ }^{189}$ to periodically change beneficiaries. Designating an international organization as the beneficiary would also solve this problem as the organization would then be able to use the funds wherever it determined the need was greatest.

\section{Human Heritage Wealth Fund}

Instead of relying on an array of private arrangements to provide benefits piecemeal, the United States could instead create a single, national fund using a sovereign wealth fund model. ${ }^{190}$ Rather than safeguarding America's sovereign wealth, this fund could be termed a "human heritage wealth fund" because it would safeguard some of the wealth obtained from the common resources of outer space, which is considered to be "the province of all mankind."191

An independent agency would be established to administer the fund, and applicants would be required to deposit payments into the national fund instead

188 Progressive Taxes, IRS, https://apps.irs.gov/app/understandingTaxes/student/whys_thm 03 les03.jsp [https://perma.cc/N6WL-Q7X5] ("A progressive tax takes a larger percentage of income from high-income groups than from low-income groups and is based on the concept of ability to pay. . . The U.S. federal income tax is based on the progressive tax system.").

189 A special (or limited) power of appointment allows the settlor of a trust (in this case, the applicant) to change the beneficiaries as desired, but not to appoint itself as a beneficiary. Powers of Appointment, INVESTOPEDIA, http:/www.investopedia.com/exam-guide/cfp/liquidityappointment-trusts $/ \mathrm{cfp} 3 . \operatorname{asp} ? \mathrm{ad}=\operatorname{dirN} \& \mathrm{qo}=$ investopediaSiteSearch\&qsrc $=0 \& \mathrm{o}=40186[\mathrm{https}: / /$ perma.cc/ZJC8-LFAC].

${ }^{190}$ According to the Sovereign Wealth Fund Institute, a sovereign wealth fund is "a state-owned investment fund or entity that is commonly established from balance of payments surpluses, official foreign currency operations, the proceeds of privatizations, governmental transfer payments, fiscal surpluses, and/or receipts resulting from resource exports." Of the five traditional classifications of such funds, two that are particularly relevant here are "Savings or Future Generation Funds" and "Strategic Development" funds. What Is a SWF?, SWFI, http://www.swfinstitute.org/sovereign-wealth-fund/ [https://perma.cc/ 47KY-75D6].

191 Outer Space Treaty, supra note 4, art. 1, para. 1. 
of private space resource trusts. The idea behind such a resource-based sovereign wealth fund would be to allow all humanity to currently benefit from space resources and to provide a legacy to benefit future generations. Considering the Outer Space Treaty's provisions about benefiting "all countries" and "use of outer space [being] the province of all mankind,"192 this type of approach may come the closest to satisfying the altruistic quality of these obligations. If established, it appears such a fund would be the first of its kind. ${ }^{193}$

Advantages to this approach could be substantial. First, the United States would stand to gain international goodwill. International reputation is a valuable commodity, and establishing such a ground-breaking fund for the general benefit of humanity would send a strong signal that the United States takes its international obligations seriously and is setting a high bar for everyone else. Second, the United States would get ahead of any criticisms that it is not meeting its international obligations. A program such as this would be difficult for other states to argue against given that it broadly interprets the obligations in the Outer Space Treaty and directly addresses the beneficial requirements imposed by them. Such a bold action would undoubtedly move the ball forward in discussions about the meaning of the Outer Space Treaty's obligations, and the previously mentioned increase in goodwill would place the United States in a stronger position to help shape any clarification of those obligations.

Other benefits of this approach include simplicity for applicants, and the large potential for a legacy. Rather than having to establish their own trusts or negotiate participation with international partners, this provides a standardized and consistent requirement that applicants can easily account for in their plans. It would also be easier for beneficiaries of one fund to be adjusted over time by the administering agency, as compared to the beneficiaries of a multitude of trusts.

Over the long term, if the fund is managed to preserve the corpus and create a legacy that provides benefits only from the earnings of the fund, the eventual size of the earnings could allow the United States to save taxpayer dollars by reducing its foreign aid budget. ${ }^{194}$ Countries benefiting from the human heritage wealth fund may not require the same level of aid, so current foreign aid funds could be reallocated for other purposes domestically. Also, the agency's costs

192 Id.

${ }^{193}$ Currently, it appears that all sovereign wealth funds have been established for the benefit of a particular single country or subnational jurisdiction. See Sovereign Wealth Fund Rankings, SWFI, http://www.swfinstitute.org/sovereign-wealth-fund-rankings/ [https://perma.cc/ 76RJ-CL5J].

194 The world's largest sovereign wealth fund (Norway) recently surpassed $\$ 1$ trillion in value. Holly Ellyatt \& Katrina Bishop, The World's Biggest Sovereign Wealth Funds in 2017: 1. Norway's Government Pension Fund Global, CNBC (Sept. 20, 2017), https://www.cnbc.com/2015/07/17/the-worlds-biggest-sovereign-wealth-funds.html\#slide=11 [https://perma.cc/U6VY-8FSR]. If the Norway fund earns a relatively modest $5 \%$ annually, its earnings in 2018 will be at least $\$ 50$ billion. By comparison, the total U.S. foreign aid budget for fiscal year 2018 is planned to be only $\$ 25.8$ billion. ForEIGNASSISTANCE.GOV, http://beta.foreignassistance.gov/ [https://perma.cc/3MM5-TCPD]. 
would be borne by the fund, so no administrative costs would be passed on to taxpayers.

Challenges to this approach include significant political issues. First is the need for legislation to establish a new agency and national fund for an unprecedented purpose. Significant political will would be needed and advocacy groups may be potentially difficult to find as the beneficiaries of the fund would be primarily foreign entities. Another political challenge is the potential of funds being raided by Congress to satisfy short-term budget needs. ${ }^{195}$ The U.S. government may also attempt to use the fund as a foreign policy tool. Rather than keeping to the broader perspective of the fund as benefitting all countries, there will be a temptation to use the fund as leverage to reward friends or punish opponents. The administering agency needs to be as independent as possible, and could be modeled on other federal agencies that enjoy a significant degree of insulation from day-to-day political whims. ${ }^{196}$

There is the possibility, in the long term, of setting up an international organization to serve as trustee of the funds to administer in accordance with the direction of the international community. This would serve to remove the funds from the reach of domestic U.S. politics and reduce the political challenges noted above. However, using an international organization could also generate its own controversy. ${ }^{197}$

${ }^{195}$ In the past, the same has happened with the national Social Security Trust Fund and Highway Trust Fund. Merrill Matthews, What Happened to the \$2.6 Trillion Social Security Trust Fund?, FORBES (July 13, 2011), https://www.forbes.com/sites/Merrillmatthews/2011/07/ 13/what-happened-to-the-2-6-trillion-social-security-trust-fund/\#2bb2080b4947 [https://perma.cc/ EY32-S6XY] (explaining how even though the government created a special trust fund to retain assets for Social Security, Congress has borrowed those funds for other purposes, thereby requiring current Social Security expenses to be paid with borrowed funds); Tax Analysts, The Gas Tax Doesn't Work Because Politicians Broke It, FORBES (Oct. 24, 2013), $\mathrm{https}$ ://www.forbes.com/sites/taxanalysts/2013/10/24/the-gas-tax-doesnt-work-because-politiciansbroke-it/\#441250a46bf1 [https://perma.cc/CV5K-ZVUT] (explaining how Congress redirected taxes earmarked for the Highway Trust Fund to deficit reduction from 1990-1997).

196 The Securities and Exchange Commission and the Federal Reserve are commonly viewed as enjoying a significant measure of independence from political actors. Adrian Vermeule, Conventions of Agency Independence, 113 CoLuM. L. REV. 1163, 1166 (2013). A combination of formal and informal factors come together to truly create independence for an agency. Id. at 1197-98 (describing how the Federal Reserve's independence results from the combination of the politics of the process of appointing the Chair, public perception, and an apparent belief by presidents that affording independence to the Federal Reserve is good policy).

197 The U.N. Oil-for-Food exchange program, while not a trust, was a similar program at the international level where Iraqi oil revenues were placed in escrow for the benefit of the Iraqi people with a U.N. agency serving as gatekeeper for the funds. Office of the Iraq Programme, About the Programme: Oil-for-Food, http://www.un.org/depts/oip/background/ index.html [https://perma.cc/3V7G-M76J] (last updated Nov. 4, 2003). Unfortunately, controversy enveloped the program, resulting in a formal inquiry that revealed bribes and kick-backs. Press Release, Head of Oil-For-Food Inquiry Calls for Wide-Ranging Reform Within United Nations, U.N. Press Release IK/524-ORG/1449 (Oct. 27, 2005), http://www.un.org/press/en/2005/ik524.doc.htm [https://perma.cc/PRQ8-SBDA]. 
A significant benefit to this arrangement, however, is that it allows the United States to shift the debate about who benefits from the space resource activities into the lap of the international community. The United States would have done its part in creating a benefit; it could not then be criticized for whether and how those benefits are distributed. The international community would then be responsible for making these decisions. ${ }^{198}$ This would also be the clearest way for the United States to satisfy its obligation to benefit all countries - by giving all countries collectively both rights and duties over the funds.

As discussed above, there are several possible approaches for attempting to satisfy the Outer Space Treaty's obligations even without international agreement as to the exact nature of the obligations. Since it seems that an international agreement clarifying the Outer Space Treaty's obligations is unlikely to occur in the near future, ${ }^{199}$ the United States is in a position to attempt to shape the international understanding of the obligations and methods of satisfying them through its own practice. ${ }^{200}$ The Human Heritage Wealth Fund provides the most direct evidence of a good-faith effort to interpret and implement the obligations, which encourages other countries to follow suit. It balances the United States' interests in pursuing resource extraction, while still recognizing the rights of other parties to the Outer Space Treaty. It would not abuse the United States' position as the first country to pursue resource extraction, and would give effect to all the treaty provisions, including those promoting the use of space for the benefit of all countries. Although the political challenges would be significant, they will only increase as time passes. After companies actually begin extraction, any legal changes could result in substantial financial consequences. Now is the time for the United States to be a leader and pursue a path that has broad benefits for everyone.

198 Such an international regime was established by the 1994 Agreement to the U.N. Convention on the Law of the Sea regarding the extraction and use of minerals on the deep seabed. About the International Seabed Authority, INT'L SEABED AUTHORITY, https://www.isa.org.jm/authority [https://perma.cc/4ZHF-QY77] ("The International Seabed Authority is an autonomous international organization ... through which States Parties to the Convention shall, in accordance with the regime for the seabed and ocean floor and subsoil thereof beyond the limits of national jurisdiction (the Area) . . , organize and control activities in the Area, particularly with a view to administering the resources of the Area."). The Moon Agreement contemplates an international regime governing space resources, but such a regime has not been created. Moon Agreement, supra note 8, art. 11, para. 5.

${ }^{199}$ Simpson, supra note 12, at 182 (noting what seems to be "a treaty-averse political climate in the United States and elsewhere").

200 See id. at 183 (suggesting that an international regime be created through the coordination of national laws rather than through a treaty); von der Dunk, supra note 69, at 28 ("[U]ltimately it is up to the states concerned to create the state practice and opinio juris which could lead to authoritative interpretations [of issues raised by the Outer Space Treaty]."). 


\section{CONCLUSION}

As recently as the 1950s, humanity had only dreams and aspirations of reaching outer space. The launch of the first Sputnik changed the world forever, and humanity rapidly began to realize some of those fantastic dreams. Although the pace of progress has slowed, with no manned missions beyond Earth orbit since $1972,{ }^{201}$ dreams and aspirations continue.

The legal regime that was created in the 1960s put in place a visionary foundation meant to guide future space activities. While it has worked so far, the world is now facing situations that this venerable foundation does not have the details to address. Technological progress is quickly providing us with the possibility of mining resources on the Moon, asteroids, and possibly even Mars and beyond. Who controls these resources? Can they be owned? By whom, and under what circumstances? These questions remain inadequately answered as international space law stands today. As history has repeatedly shown, where there are valuable resources, conflict often results when control of those resources is unclear.

The ability of humanity to avoid resource conflicts in space is critical to the realization of the ideals of the Outer Space Treaty. These ideals are worth realizing because they provide the foundation upon which humanity can reshape its future. In the apparent absence of a willingness to explicitly clarify the Outer Space Treaty, it is the subsequent practice of the parties to the Treaty that will shape the detailed understanding of rights and obligations with regard to space resources. The United States has gone out on a limb to recognize private rights in space resources in a new law without the support of other countries; it now must use its law to shape the actions of other states into subsequent practice.

Since agreement is the necessary element of subsequent practice, only an approach to implementing the United States' law that encourages participation by other countries will achieve its goals, not an approach that leads to objections. This is a chance for the United States to both get behind private enterprise, recognizing it as the main driver of future space activities, and to ensure that space is truly a frontier for all of humanity. Outer space is vast, and so are its resources. Why not start the next chapter of human endeavor in space by sharing its vast benefits with an inclusive and ambitious vision? Done right, such a vision might even put the United States in the captain's chair leading humanity's next leap into space with a willing world community.

201 The last manned mission to the Moon, Apollo 17, returned to Earth on December 19, 1972. The Apollo 17 Mission, NAT'L AERONAUTICS \& SPACE ADMIN., http://spaceflight.nasa.gov/history/apollo/apollo17/index.html [https://perma.cc/VHD4-8WM4] (last updated July 2, 2009). 